\title{
Time-Scale Decomposition of Price Transmission in International Markets
}

\author{
Viviana Fernandez ${ }^{1}$
}

\begin{abstract}
This article focuses on return spillovers in stock markets at different time scales using wavelet analysis. We look at eight stock indices that comprise the G7 countries, Emerging Asia, Europe, Eastern Europe and the Middle East, the Emerging Far East, Latin America, North America, and the Pacific region for the period 1990-2002.

Our estimation results show evidence of price spillovers from the G7 countries to Europe, Eastern Europe and the Middle East, Emerging Asia, Europe, Latin America, and North America. However, price spillovers of these regions to the G7 countries are weaker at different time scales. Similarly, we find price spillovers from North America to Latin America, Emerging Asia, the Emerging Far East, and the Pacific region, and from both Europe and Latin America to North America. Our results are robust to the existence of asymmetric GARCH-effects and serial correlation in returns.
\end{abstract}

JEL: C22, G15 Keywords: spillovers, wavelet analysis, A-PGARCH models.

\footnotetext{
${ }^{1}$ Center for Applied Economics (CEA), Department of Industrial Engineering at the University of Chile. Postal: Avenida Republica 701, Santiago-Chile. E-mail: vfernand@dii.uchile.cl. Funds provided by an institutional grant of the Hewlett Foundation to CEA are greatly acknowledged. All remaining errors are the author's.
} 


\section{Introduction}

In the past few years, international transmission of stock market returns and volatility in international financial markets has become an active research area in finance. For instance, Karolyi (1995) focuses on the short-run dynamics of returns and volatility for stocks traded on the New York and Toronto stock exchanges. He concludes that both the magnitude and persistence of return innovations from one market to the other depend to great extent on how the cross-market dynamics in volatility are modeled. In turn, $\mathrm{Ng}$ (2000) looks at spillovers from Japan and the United States to six countries of the Pacific Basin. She finds that, after controlling for the impact of the United States, there are significant spillovers from Japan to many of the Pacific-Basin countries. Moreover, liberalization of capital markets, exchange rate changes, sizes of trade, among other factors, affect the relative importance of the U.S. and Japan over time. More recently, Worthington and Higgs (2004) examined the transmission of equity returns and volatility among three developed Asian stock markets (Hong Kong, Japan, and Singapore) and six emerging Asian stock markets (Indonesia, Korea, Malaysia, the Philippines, Taiwan, and Thailand). Their results generally indicate the presence of large and predominantly positive mean and volatility spillovers.

Another strand of the literature has focused on testing the existence of contagion in international financial markets. Although, there is not a unique definition of contagion, this is usually thought of as correlation between markets in excess of what economic fundamentals would predict. In a recent article, Forbes and Rigobon (2002) distinguish between contagion and interdependence. They define contagion as a significant increase in cross-market linkages after one country or a group of countries experience a shock. Otherwise, if co-movement does not increase significantly, but a high level of correlation persists in all periods, Forbes and Rigobbon call it interdependence. By using a correlation coefficient adjusted by market volatility, they conclude that there was not contagion during the Asian crisis, the 1994 Mexican devaluation, and the 1987 U.S. market. Instead, they find only high levels of market co-movements through time or interdependence. More recently, Karolyi (2003) has surveyed the various definitions of financial contagion. He distinguishes between two categories of contagion. The first one refers to co-movements in asset prices that result from normal interdependence, while the second one involves financial crises that are not necessarily linked to macroeconomic factors or other fundamentals.

A drawback of correlation coefficients is that they give the same weight to extreme observations. Therefore, they are not an accurate measure of dependence if extreme observations present different patterns of dependence from the rest of the sample. Based on this fact, the most recent literature on interdependence has resorted to extreme value theory. For instance, Poon, Rockinger, and Tawn (2003) control for asset returns heteroscedasticity before testing for extremal dependence. Their estimation results show that tail dependence decreases to great extent when conditional heteroscedasticity is filtered out by univariate and bivariate GARCH-models. In addition, Poon et al. find that extremal dependence is usually stronger in bear markets (left tails) than in bull markets (right tails). 
To date, the statistical techniques commonly used to quantify price transmission are vector autorregresive regression (VAR) systems (e.g., Eun and Shim, 1989), multivariate generalized autorregresive conditional heteroscedasticity (GARCH) models (e.g., Lin, Engle, and Ito, 1994; Karolyi and Stulz, 1996), multivariate generalized autoregressive conditional heteroscedasticity (M-GARCH) models (e.g., Worthington and Higgs, op. cit), correlation coefficients corrected for heteroscedasticity to account for varying volatility (e.g., Forbes and Rigobon, op. cit), and extreme value theory (e.g., Poon et al., op cit). An alternative, but promising, approach that has received less attention in both finance and economics is wavelet analysis. This is a refinement of Fourier analysis that was developed in the late 1980's, and which offers a powerful methodology for processing signals, images, and other types of data. In particular, the discrete wavelet transform allows for the decomposition of time series data into orthogonal components with different frequencies. This makes it possible to quantify correlations between markets at different time horizons.

Recent applications of wavelet methods in economics and finance are Ramsey and Lampart (1998), Norsworthy, Li and Gorener (2000), Lee (2001a, 2001b), and Gençay, Whitcher, and Selcuk (2002). Ramsey and Lampart (1998) study the permanent income hypothesis, and conclude that time-scale decomposition is very important to analyzing economic relationships. In particular, they find that an appropriate way to model the consumption-income relationship during the post-war period is at the time scale dominated by a trend. At lower scales (i.e., higher frequencies), the degree of fit and the slope of the consumption-income relationship declines monotonically, except for the lowest scale.

Norsworthy, Li and Gorener (2000) and Gençay, Whitcher, and Selcuk (2002) apply wavelet analysis to estimate the systematic risk of an asset (beta). The main conclusion of Norsworthy et al. is that the major part of the market's influence on an individual asset return is at higher frequencies. In other words, the beta coefficient will generally decrease when regressing an individual asset return on the smoother components of the market portfolio. Moreover, the $\mathrm{R}^{2}$ of the CAPM regression will generally decline as the frequency decreases. This implies that non-systematic risk will be captured primarily in lower frequency movements. Unlike Norsworthy et al., who regress an individual asset return on different time-scales of the market return, Gençay et al. focus on a portfolio and calculate the wavelet variance of the market return and the wavelet covariance between the market return and the portfolio return at each scale to obtain the portfolio beta. Their finding is that the relationship between the return on a portfolio and its beta becomes stronger as the scale increases. That is to say, the predictions of the CAPM model are more relevant at the medium-term than at short-time horizons.

Lee (2001a) studies the interaction between the U.S. and the South Korean stock markets. Using the KOSPI and the DJIA, and the KOSDAQ and the NASDAQ, he finds evidence of price and volatility spillover effects from the U.S. to South Korea, but not vice versa. Lee concludes that his findings confirm the importance of innovations in developed stock markets to the determination of stock returns and volatility in emerging economies. In turn Lee (2001b) illustrates the use of wavelet analysis for seasonality filtering of timeseries data. 
This article focuses on normal interdependence among stock markets by quantifying return spillovers at different time scales. We look at eight stock indices that include the G7 countries, Emerging Asia, Europe, Eastern Europe and the Middle East, the Emerging Far East, Latin America, North America, and the Pacific region for the period 1990-2002. The contribution of our work is twofold. First, we extend previous research on the area of price transmission by considering a sample of various developed and emerging regions. Second, we test the robustness of our results for both conditional volatility and serial correlation in returns (inertia). To our knowledge, no one has pursued similar research so far.

The article is organized as follows. Section II gives a brief background on wavelet analysis. Section III focuses on return spillovers for a sample of eight stock indices worldwide using wavelet methods. We test the robustness of our results for the presence of asymmetric GARCH-effects and serial correlation in returns. Finally, Section IV presents our main conclusions.

\section{Wavelet Analysis}

Wavelets or short waves are similar to sine and cosine functions in that they also oscillate about zero. However, as its name indicates, oscillations of a wavelet fade away around zero, and the function is localized in time or space. ${ }^{2}$ In wavelet analysis, a signal (i.e., a sequence of numerical measurements) is represented as a linear combination of wavelet functions.

Unlike Fourier series, wavelets are suitable building-block functions for signals whose features change over time, and for non-smooth signals. A wavelet allows for decomposing a signal into multi-resolution components: fine and coarse resolution components.

There are father wavelets $\phi$ and mother wavelets $\psi$ such that

$$
\int \phi(\mathrm{t}) \mathrm{dt}=1 \quad \int \psi(\mathrm{t}) \mathrm{dt}=0
$$

Father wavelets are good at representing the smooth and low-frequency parts of a signal, whereas mother wavelets are good at representing the detailed and high-frequency parts of a signal. The most commonly used wavelets are the orthogonal ones: haar, daublets, symmelets, and coiflets. The haar wavelet is a square wave with compact support (i.e., it is zero outside a finite interval), and it is the only orthogonal wavelet that is symmetric. However, it is not continuous. By contrast, daublets are continuous with compact support, but they are quite asymmetric. Symmlets have also compact support, and were constructed to be as symmetric as possible. Finally, coiflets were also constructed to be least asymmetric, and have vanishing moments for both father and mother wavelets. Figure 1 illustrates these different orthogonal wavelets.

\section{[Figure 1]}

\footnotetext{
${ }^{2}$ Mathematically, a function $\varpi($.$) defined over the entire real axis is called a wavelet if \varpi(t) \rightarrow 0$ as $t \rightarrow \pm \infty$.
} 
The orthogonal wavelet series approximation to a continuous signal $f(t)$ is given by

$$
\mathrm{f}(\mathrm{t}) \approx \sum_{\mathrm{k}} \mathrm{s}_{J, \mathrm{k}} \phi_{J, k}(\mathrm{t})+\sum_{\mathrm{k}} \mathrm{d}_{J, \mathrm{k}} \psi_{J, \mathrm{k}}(\mathrm{t})+\sum_{\mathrm{k}} \mathrm{d}_{J-1, \mathrm{k}} \psi_{J-1, \mathrm{k}}(\mathrm{t})+\ldots+\sum_{\mathrm{k}} \mathrm{d}_{1, \mathrm{k}} \psi_{1, \mathrm{k}}(\mathrm{t}),
$$

where $\mathrm{J}$ is the number of multi-resolution components or scales, and $\mathrm{k}$ ranges from 1 to the number of coefficients in the corresponding component. The coefficients $\mathrm{s}_{\mathrm{J}, \mathrm{k}}, \mathrm{d}_{\mathrm{J}, \mathrm{k}}, \ldots, \mathrm{d}_{1, \mathrm{k}}$ are the wavelet transform coefficients, whereas the functions $\phi_{\mathrm{j}, \mathrm{k}}(\mathrm{t})$ and $\psi_{\mathrm{j}, \mathrm{k}}(\mathrm{t})$ are the approximating wavelet functions. These functions are generated from $\phi$ and $\psi$ as follows:

$$
\phi_{j, k}(t)=2^{-j / 2} \phi\left(\frac{t-2^{j} k}{2^{j}}\right) \quad \psi_{j, k}(t)=2^{-j / 2} \psi\left(\frac{t-2^{j} k}{2^{j}}\right)
$$

Expression (2) is an orthogonal approximation because the basis functions $\phi_{\mathrm{j}, \mathrm{k}}(\mathrm{t})$ and $\psi_{\mathrm{j}, \mathrm{k}}(\mathrm{t})$ are orthogonal by construction

$$
\begin{aligned}
& \int \phi_{J, k}(t) \phi_{J, k^{\prime}}(t) d t=\delta_{k, k^{\prime}} \\
& \int \psi_{j, k}(t) \phi_{J, k^{\prime}}(t) d t=0 \\
& \int \psi_{j, k}(t) \psi_{j^{\prime}, k^{\prime}}^{\prime}(t) d t=\delta_{j, j^{\prime}} \delta_{k, k^{\prime}},
\end{aligned}
$$

where $\delta_{i, j}=\left\{\begin{array}{ll}1 & \text { if } \mathrm{i}=\mathrm{j} \\ 0 & \text { if } \mathrm{i} \neq \mathrm{j}\end{array}\right.$.

The wavelet coefficients can be approximated by the following integrals

$$
\mathrm{s}_{\mathrm{J}, \mathrm{k}} \approx \int \phi_{\mathrm{J}, \mathrm{k}}(\mathrm{t}) \mathrm{f}(\mathrm{t}) \mathrm{dt} \quad \mathrm{d}_{\mathrm{j}, \mathrm{k}} \approx \int \psi_{\mathrm{j}, \mathrm{k}}(\mathrm{t}) \mathrm{f}(\mathrm{t}) \mathrm{dt}, \mathrm{j}=1,2, \ldots, \mathrm{J} .
$$

These coefficients are a measure of the contribution of the corresponding wavelet function to the total signal. On the other hand, the approximating wavelet functions $\phi_{\mathrm{j}, \mathrm{k}}(\mathrm{t})$ and $\psi_{\mathrm{j}, \mathrm{k}}(\mathrm{t})$ are scaled and translated versions of $\phi$ and $\psi$. As equation (3) indicates, the scale or dilation factor is $2^{j}$, whereas the translation or location parameter is $2^{j} \mathrm{k}$. As j gets larger, so does the scale factor $2^{\mathrm{j}}$, and the functions $\phi_{\mathrm{j}, \mathrm{k}}(\mathrm{t})$ and $\psi_{\mathrm{j}, \mathrm{k}}(\mathrm{t})$ get shorter and more spread out. In other words, $2^{j}$ is a measure of the width of the functions $\phi_{\mathrm{j}, \mathrm{k}}(\mathrm{t})$ and $\psi_{\mathrm{j}, \mathrm{k}}(\mathrm{t})$. Likewise, as $\mathrm{j}$ increases, the translation step gets correspondingly larger in order to match the scale parameter $2^{\mathrm{j}}$.

In general, there is no close-form solution for wavelets functions. Therefore, they have to be computed by the so-called dilation equations. For a father wavelet $\phi(x)$, the dilation equation is defined by

$$
\phi(\mathrm{x})=\sqrt{2} \sum_{\mathrm{k}} 1_{\mathrm{k}} \phi(2 \mathrm{x}-\mathrm{k}) .
$$


The mother wavelet can be obtained from the father wavelet by the relationship

$$
\psi(\mathrm{x})=\sqrt{2} \sum_{\mathrm{k}} \mathrm{h}_{\mathrm{k}} \phi(2 \mathrm{x}-\mathrm{k}) .
$$

The $l_{k}$ and $h_{k}$ coefficients are called the scaling (low-pass) and wavelet (high-pass) filter coefficients, respectively, which are defined by

$$
1_{\mathrm{k}}=\frac{1}{\sqrt{2}} \int \phi(\mathrm{t}) \phi(2 \mathrm{t}-\mathrm{k}) \mathrm{dt} \quad \mathrm{h}_{\mathrm{k}}=\frac{1}{\sqrt{2}} \int \psi(\mathrm{t}) \phi(2 \mathrm{t}-\mathrm{k}) \mathrm{dt}
$$

and, they are related through $\mathrm{l}_{\mathrm{k}}=(-1)^{\mathrm{k}+1} \mathrm{~h}_{\mathrm{L}-1-\mathrm{k}}, \mathrm{k}=0, . ., \mathrm{L}-1$, where $\mathrm{L}$ is the width of the wavelet filter. ${ }^{3}$

Applications of wavelet analysis commonly make use of a discrete wavelet transform (DWT). The DWT calculates the coefficients of the approximation in (2) for a discrete signal of final extent, $f_{1}, f_{2}, \ldots, f_{n}$. That is, it maps the vector $\mathbf{f}=\left(f_{1}, f_{2}, \ldots, f_{n}\right)^{\prime}$ to a vector $\boldsymbol{\omega}$ of $n$ wavelet coefficients that contains $s_{J, k}$ and $d_{j, k}, j=1,2, \ldots, J$. The $s_{J, k}$ are called the smooth coefficients and the $\mathrm{d}_{\mathrm{j}, \mathrm{k}}$ are called the detail coefficients. Intuitively, the smooth coefficients represent the underlying smooth behavior of the data at the coarse scale $2^{\mathrm{J}}$, whereas the detail coefficients provide the coarse scale deviations from it.

When the length of the data $n$ is divisible by $2^{\mathrm{J}}$, there are $\mathrm{n} / 2$ coefficients $\mathrm{d}_{1, \mathrm{k}}$ at the finest scale $2^{1}=2$. At the next finest scale, there are $n / 2^{2}$ coefficients $d_{2, k}$. Similarly, at the coarsest scale, there are $n / 2^{\mathrm{J}} \mathrm{d}_{\mathrm{J}, \mathrm{k}}$ coefficients and $\mathrm{n} / 2^{\mathrm{J}} \mathrm{s}_{\mathrm{J}, \mathrm{k}}$ coefficients. Altogether, there are $\mathrm{n}\left(\sum_{\mathrm{i}=1}^{\mathrm{J}} \frac{1}{2^{\mathrm{i}}}+\frac{1}{2^{\mathrm{J}}}\right)=\mathrm{n}$ coefficients. The number of coefficients at a given scale is related to the width of the wavelet function. For instance, at the finest scale, it takes $n / 2$ terms for the functions $\psi_{1, \mathrm{k}}(\mathrm{t})$ to cover the interval $1 \leq \mathrm{t} \leq \mathrm{n}$.

The wavelet coefficients are ordered from coarse scales to fine scales in the vector $\omega$. If $\mathrm{n}$ is divisible by $2^{\mathrm{J}}, \boldsymbol{\omega}$ will be given by

\footnotetext{
${ }^{3}$ In practical applications, we deal with sequences of values (i.e., time series) rather than functions defined over the entire real axis. Therefore, instead of using actual wavelets, we work with short sequences of values named wavelet filters, denoted by $\left\{\mathrm{h}_{\mathrm{k}}\right\}_{\mathrm{k}=0}^{\mathrm{L}}$. The number of values in the sequence is called the width of the wavelet filter, and it is denoted by $L$. The filter coefficients must satisfy the following: $\sum_{k=0}^{L-1} h_{k}=0, \sum_{k=0}^{L-1} h_{k}^{2}=1$, $\sum_{k=0}^{L-1} h_{k} h_{k+2 j}=0$, where $j$ is any non-zero integer.
} 


$$
\boldsymbol{\omega}=\left(\begin{array}{c}
\mathbf{s}_{\mathrm{J}} \\
\mathbf{d}_{\mathrm{J}} \\
\mathbf{d}_{\mathrm{J}-1} \\
\vdots \\
\mathbf{d}_{1}
\end{array}\right),
$$

where

$$
\begin{array}{cc}
\mathbf{s}_{\mathrm{J}}= & \left(\mathrm{s}_{\mathrm{J}, 1}, \mathrm{~s}_{\mathrm{J}, 2}, \ldots, \mathrm{s}_{\mathrm{J}, \mathrm{n} / 2^{\mathrm{J}}}\right)^{\prime} \\
\mathbf{d}_{\mathrm{J}}= & \left(\mathrm{d}_{\mathrm{J}, 1}, \mathrm{~d}_{\mathrm{J}, 2}, \ldots, \mathrm{d}_{\mathrm{J}, \mathrm{n} / 2^{\mathrm{J}}}\right)^{\prime} \\
\mathbf{d}_{\mathrm{J}-1}= & \left(\mathrm{d}_{\mathrm{J}-1,1}, \mathrm{~d}_{\mathrm{J}-1,2}, \ldots, \mathrm{d}_{\mathrm{J}-1, \mathrm{n} / 2^{\mathrm{J}-1}}\right)^{\prime} . \\
\vdots & \vdots \\
\mathbf{d}_{1}= & \left(\mathrm{d}_{1,1}, \mathrm{~d}_{1,2}, \ldots, \mathrm{d}_{1, \mathrm{n} / 2}\right)^{\prime}
\end{array}
$$

Each set of coefficients $\mathbf{s}_{\mathrm{J}}, \mathbf{d}_{\mathrm{J}}, \ldots, \mathbf{d}_{1}$ is called a crystal. ${ }^{4}$

Expression (2) can be rewritten as

$$
f(t) \approx S_{J}(t)+D_{J}(t)+D_{J-1}(t)+\ldots+D_{1}(t)
$$

where

$$
\begin{aligned}
& \mathrm{S}_{J}(\mathrm{t})=\sum_{\mathrm{k}} \mathrm{s}_{J, \mathrm{k}} \phi_{J, k}(\mathrm{t}) \\
& \mathrm{D}_{J}(\mathrm{t})=\sum_{\mathrm{k}} \mathrm{d}_{\mathrm{j}, \mathrm{k}} \psi_{J, \mathrm{k}}(\mathrm{t})
\end{aligned}
$$

are denominated the smooth signal and the detail signal, respectively.

The terms in expression (10) represent a decomposition of the signal into orthogonal signal components $\mathrm{S}_{\mathrm{J}}(\mathrm{t}), \mathrm{D}_{\mathrm{J}}(\mathrm{t}), \mathrm{D}_{\mathrm{J}-1}(\mathrm{t}), \ldots, \mathrm{D}_{1}(\mathrm{t})$ at different scales. These terms are components of the signal at different resolutions. That is why the approximation in (10) is called a multi-resolution decomposition (MRD).

\footnotetext{
${ }^{4}$ In practice, the DWT is calculated by using a filter cascade, where the wavelet filter $\left\{h_{k}\right\}$ and its associated scaling filter $\left\{l_{k}\right\}$ given by (8), are used in a pyramid algorithm to decompose a time series. To generate the first level of coefficients, the original data is filtered by convolving it separately with the wavelet and scaling filters. Next, every other point from each filter output is thrown out, and the remaining filter outputs are defined as the unit level $(j=1)$ wavelet and scaling coefficients. For $\mathrm{j}=2$, the same filtering/ decimation scheme is utilized, but the unit-level scaling coefficients are the input to the filters. At the jth level, the inputs to the wavelet and scaling filters are the scaling coefficients from the previous (j-1) level, and the outputs are the jth level wavelet and scaling coefficients.
} 


\section{Data and Estimation Results}

\subsection{Description of the Data}

We work with eight regional equity indices of Morgan Stanley: Latin America (Argentina, Brazil, Chile, Colombia, Mexico, Peru, and Venezuela), North America (Canada and the United States), Emerging Asia (China, India, Indonesia, Korea, Malaysia, Pakistan, Philippines, Taiwan, and Thailand), Europe (Austria, Belgium, Denmark, Finland, France, Germany, Greece, Ireland, Italy, Luxembourg, Netherlands, Norway, Portugal, Spain, Sweden, and the United Kingdom), Europe \& the Middle East (Czech Republic, Hungary, Israel, Jordan, Poland, Russia, and Turkey), Pacific (Australia, Hong Kong, Japan, New Zealand, and Singapore), the Emerging Far East (China, Indonesia, Korea, Malaysia, Philippines, Taiwan, and Thailand) and G7 (Canada, France, Germany, Italy, Japan, the United Kingdom, and the United States). All indices are free-float adjusted by market capitalization, and are expressed in U.S. dollars. Index values are measured at closing time. The sample period is 1990-2002, and the data are measured on a daily frequency. Computations were carried out with S+Wavelets 2.0.

Table 1 presents some descriptive statistics of daily returns on each index. Over the sample period, the most volatile returns were those on the Latin America and the Europe \& the Middle indices. Moreover, Latin America had the greatest returns range among all indices with a minimum of -14.5 percent and a maximum of 13.5 percent. By contrast, the returns on the G7 index exhibited both the lowest volatility and the lowest range. All returns. All return series departure significantly from normality, due to their high excess kurtosis.

[Table 1]

The energy concentration function for a vector $\mathbf{x}=\left(\mathrm{x}_{1}, \mathrm{x}_{2}, \ldots, \mathrm{x}_{\mathrm{n}}\right)^{\prime}$ is defined by

$$
E_{x}(K)=\frac{\sum_{i=1}^{K} x_{(i)}^{2}}{\sum_{i=1}^{n} x_{i}^{2}},
$$

where $\mathrm{x}_{(\mathrm{i})}$ is the ith-largest absolute value in $\mathbf{x}$. That is, the energy in a given crystal is calculated as the sum of squares of all of its elements over the sum of squares of all observations in the original time series. One appealing characteristic of the DWT is that it is an energy preserving transform. This means that the energy in all the DWT coefficients equals the energy in the original time series.

For our data, the coefficients at the two finest scales $2^{1}$ and $2^{2}$ concentrate in all cases over 60 percent of the energy. For instance, the economic region with the highest concentration of energy in crystals D1 and D2 is North America with 74.7 percent, while the one with the lowest concentration is Emerging Asian with 64.2 percent. This implies that fluctuations in returns take place primarily in the short run. This is depicted in Figure 2, where we present a multi-resolution decomposition for each return series. At each scale, the 
corresponding component is reconstituted according to equations (11a) and (11b). Most short-run fluctuations are observed in the two finest components D1 and D2, and some in the third (i.e., 8-day horizon). Meanwhile, medium-term fluctuations are captured at the coarser levels (i.e., within 16 and 64 days).

\subsection{Returns Spillovers}

[Figure 2]

As stated in the previous section, most variation in returns is observed in the short run. Therefore, if we consider the paired returns $\left(\mathrm{X}_{1}, \mathrm{X}_{2}\right), \mathrm{X}_{1}$ will exhibit higher correlation with the finest components of $\mathrm{X}_{2}$ than with its coarser levels. Figure 3 illustrates this point for the return on the Latin America index and the return on the G7 index. The left-hand side plot shows the Latin America daily return on the first crystal (D1) of the G7 daily return, while the right-hand side plot shows the Latin America daily return on the fifth crystal (D5) of the G7 daily return.

[Figure 3 about here]

Based on this evidence, we study the relationship between paired returns by focusing on the first two crystals of each series. Specifically, as in Lee (2001a), if we have the $\left(X_{1}, X_{2}\right)$ pair, we run a regression of $X_{1}$ on the finest component of $X_{2}(D 1)$, and a second regression of $X_{1}$ on the sum of the two finest components of $X_{2}(D 1+D 2)$, and vice versa. We look at different combinations of return pairs for the sample of eight indices. Specifically, we consider five different groups of regressions: G7, Pacific, Latin America, North America and Europe. ${ }^{5}$

Due to non-synchronous trading in some cases, we look at the relationship between the lagged return of one region and the contemporaneous return on the other region. For instance, when analyzing spillovers from Latin America to the Pacific region, we regress the contemporaneous return on the Pacific region on the lagged return on Latin America, and its D1 and (D1+D2) components. Conversely, when analyzing spillovers from the Pacific region to Latin America, we regress the contemporaneous return on Latin America on the contemporaneous return on the Pacific region, and its D1 and (D1+D2) components.

Table 3 presents our estimation results. Panel (a) presents regressions for the G7 countries vis-à-vis Europe, Europe and the Middle East, Emerging Asia, the Emerging Far East, Latin America, North America, and the Pacific region. In general, price spillovers from the G7 stock markets to these other regions are stronger than in the opposite direction. Specifically, Europe, Latin America, and North America in particular, appear as the most sensitive to the performance of the G7 countries. Not surprisingly, such price transmission is largest for North America, given that both Canada and the United States are part of the G7 countries.

The regressions for the Pacific region, in Panel (b), show that price spillovers between Emerging Asia and the Pacific region are strong in both directions. There are also

\footnotetext{
${ }^{5}$ We report twenty four regressions out of the twenty eight possible combinations.
} 
spillovers from North America to the Pacific region, while spillovers from Europe, Europe and the Middle East, and Latin America do not appear to be as large. As to Latin America, spillovers from North America are clearly the most sizeable, followed by those from Europe (Panel (c)). Price transmission in the opposite direction seems to exist only for North America. The regressions also show that there are some spillovers between Emerging Asia and Latin America of similar magnitude from one region to the other. Panel (d) in turn gives account of spillovers from North America to Emerging Asia, Europe, Europe and the Middle East, the Emerging Far East, and the Pacific region. Except for Europe, there is no significant price transmission from these regions to North America. Finally, Panel (e) shows some evidence of spillovers between Europe and Emerging Asia, and between Europe and the Emerging Far East, but not fairly large.

\section{[Table 3]}

In sum, we find that stock markets in Latin America, Eastern Europe and the Middle East, Emerging Asia, and North America are particularly sensitive to the performance of the G7 stock markets. However, price transmission in the opposite direction is weaker at different time scales. Only stock markets of developed European countries and North America seem to affect those of the G7 countries. Meanwhile, the evolution of North America stock markets is particularly relevant to Europe, Latin America, Emerging Asia, the Emerging Far East, and the Pacific region. On the other hand, price spillovers to North America come primarily from Europe and Latin America.

At this point, a relevant question arises. To what extent are price spillovers an artifact of not modeling volatility explicitly? We investigate this point in the next section. As extensively documented in the finance literature, asset returns are characterized by conditional heteroscedasticity, and some lingering correlation-at least in the short run. Therefore, we postulate a new model where we control for GARCH and leverage effects, and include lagged returns in the mean equation.

\subsection{Controlling for Conditional Heteroscedasticity and Serial Correlation}

Ding, Granger and Engle (1993) analyzed the S\&P500 daily closing index from January 1928 to August 1991, and found two distinguishing features. The first is that when absolute values of stock returns are raised to a power, $\eta$, the autocorrelations appear to be highest for values of $\eta$ around 0.75 . The second is that positive autocorrelations are persistent for very high lags. This suggests that conditional variance may have a longer memory than is usually captured by a GARCH model. Therefore, Ding et al. proposed a generalization of the GARCH model called Asymmetric Power GARCH model (APGARCH):

$$
\mathrm{r}_{\mathrm{t}}=\boldsymbol{\delta}^{\prime} \mathbf{x}_{\mathrm{t}}+\varepsilon_{\mathrm{t}}, \quad \varepsilon_{\mathrm{t}}=\sigma_{\mathrm{t}} \mathrm{z}_{\mathrm{t}}, \mathrm{z}_{\mathrm{t}} \sim \operatorname{IID}(0,1), \mathrm{t}=1,2 \ldots, \mathrm{T}
$$

where

$$
\sigma_{\mathrm{t}}^{\delta}=\alpha_{0}+\sum_{\mathrm{t}=1}^{\mathrm{p}} \alpha_{\mathrm{i}}\left(\left|\varepsilon_{\mathrm{t}-\mathrm{i}}\right|+\gamma_{\mathrm{i}} \varepsilon_{\mathrm{t}-\mathrm{i}}\right)^{\delta}+\sum_{\mathrm{j}=1}^{\mathrm{q}} \beta_{\mathrm{j}} \sigma_{\mathrm{t}-\mathrm{i}}^{\delta}
$$


and $\alpha_{0}>0, \delta>0, \alpha_{i} \geq 0, i=1, \ldots, p, \beta_{j} \geq 0, j=1, \ldots, q$ and $\left|\gamma_{i}\right|<1, i=1, \ldots, p$.

They show that many other GARCH variants can be nested in the A-PGARCH model. For instance, if $\mathrm{d}=2$ and $\gamma_{\mathrm{i}}=0 \forall \mathrm{i}$, we have a GARCH model; if $\mathrm{d}=1$, we have the threshold GARCH model, etc. ${ }^{6}$ Mckenzie and Mitchell (2002) present an application of APGARCH model to seventeen bilateral exchange rates over January 1986 to December 1997. They conclude that in the presence of symmetric responses to innovations, the $\operatorname{GARCH}(1,1)$ model is preferred. When asymmetry is present, the inclusion of a leverage term is worthwhile as long as the power term is simultaneously estimated within the model.

In this section, we test whether the estimation results of Section 3.2 are robust to the presence of conditional heteroscedasticity and serial correlation in returns. For simplicity, we use an A-PGARCH $(1,1,2)$ specification for the conditional variance:

$$
\sigma_{\mathrm{t}}^{2}=\alpha_{0}+\alpha_{1}\left(\left|\varepsilon_{\mathrm{t}-1}\right|+\gamma_{1} \varepsilon_{\mathrm{t}-1}\right)^{2}+\beta_{1} \sigma^{2}
$$

As shown below, this parsimonious functional form fits the data well.

For this specification, the unconditional volatility is given by

$$
\tilde{\sigma}^{2}=\frac{\alpha_{0}}{\left(1-\alpha_{1}\left(1+\gamma_{1}^{2}\right)-\beta_{1}\right)}
$$

And, the k-step ahead forecast of volatility is given by

$$
\mathrm{E}_{\mathrm{T}}\left(\sigma_{\mathrm{T}+\mathrm{k}}^{2}\right)=\alpha_{0}\left(1+\sum_{\mathrm{i}=1}^{\mathrm{k}-2}\left(\alpha_{1}\left(1+\gamma_{1}^{2}\right)+\beta_{1}\right)^{\mathrm{i}}\right)+\left(\alpha_{1}\left(1+\gamma_{1}^{2}\right)+\beta_{1}\right)^{\mathrm{k}-1} \mathrm{E}_{\mathrm{T}}\left(\sigma_{\mathrm{T}+1}^{2}\right),(16)
$$

where

$$
\mathrm{E}_{\mathrm{T}}\left(\sigma_{\mathrm{T}+1}^{2}\right)=\alpha_{0}+\alpha_{1}\left(1-\gamma_{1}\right)^{2} \varepsilon_{\mathrm{T}}^{2}\left(\varepsilon_{\mathrm{T}}<0\right)+\alpha_{1}\left(1+\gamma_{1}\right)^{2} \varepsilon_{\mathrm{T}}^{2}\left(\varepsilon_{\mathrm{T}}>0\right)+\beta_{1} \sigma_{\mathrm{T}}^{2} .
$$

For the sake of brevity, we concentrate on spillovers from North America to Emerging Asia, Europe, and Latin America, and on spillovers from these regions to North America. Table 3 shows our results. Panel (a) shows the regressions for spillovers from North America to Emerging Asia. The mean equation of the first regression includes as explanatory variables the lagged return on the Emerging Asia Index to control for serial correlation, and the lagged return on the North America Index. Even after taking account of conditional heteroscedasticy and serial correlation, the lagged return on the North America Index is statistically significant and its magnitude is not dramatically lower than that

\footnotetext{
${ }^{6}$ Hentschel (1995) proposed a more general family of models based on the Box-Cox transformation, which nests the most popular symmetric and asymmetric GARCH models.
} 
reported in Table 2, Panel (d). Indeed, the coefficient on this variable drops from 0.463 to 0.334 .

The following two regressions replace the lagged return on the North America Index with its first crystal (D1), and with the sum of its first two crystals (D1+D2), respectively. Our conclusions remain unchanged: crystals D1 and (D1+D2) have explanatory power in each corresponding regression, and the coefficients on these variables do not vary considerable with respect to those reported in Table 2 (d). Panels (b) and (c) report analogous regressions of spillovers from North America to Europe and Latin America, respectively. As we concluded earlier, spillovers to Latin America are of greater magnitude than to Europe.

Finally, the regressions in Panels (e) and (f) attempt to measure individual spillovers from Europe and Latin America to North America. Emerging Asia is excluded because we already concluded that spillovers from this region to North America are weak. As previously found, spillovers from Latin America to North America and from Europe to North America are similar in magnitude within a four-day horizon. However, they seem to be larger from Latin America within a two-day horizon.

Consequently, if one wanted to forecast the evolution of North America returns, it would not be obvious whether to prefer Europe over Latin America. As Figure 3 shows, based on the QQ-plot of standardized residuals, the models in Tables 3(e) and 3(f) perform similarly. (The Akaike information criteria are close as well: $-22,613$ for the Latin America model and -22,442 for the Europe model). In addition, the regression of North America on Latin America's (D1+D2) gives a similar estimate of the unconditional standard deviation of returns as that of North America on Europe's (D1+D2): 9.15 and 9.41 percent, respectively.

We also computed alternative indicators of performance to compare both models. First, we ran a regression on the naive estimate of North America's return volatility-i.e., the absolute value of the daily return, $\mid r_{t} \models$ on the conditional in-sample volatility estimate given by each model. Table 4 shows the regressions. The Europe model yields a slightly better fit than the Latin America model, with an $\mathrm{R}^{2}$ of 26.43 percent.

\section{[Table 4 about here]}

In turn Figure 5(a) shows 95-percent value-at-risk (VaR) in-sample estimates, whereas Figure 5(b) presents 95-percent VaR out-of-sample forecast for different time horizons for a $\$ 10,000$ investment. The in-sample VaR for one-day horizon is computed as follows:

$$
\widehat{\operatorname{VaR}}_{\mathrm{q}}^{\mathrm{t}}=-\left(\hat{\delta}_{0}+\hat{\delta}_{1} \mathrm{r}_{\mathrm{t}-1}+\hat{\delta}_{2}\left(\mathrm{D}_{1}+\mathrm{D}_{2}\right)_{\mathrm{t}}\right)+\hat{\sigma}_{\mathrm{t}} \operatorname{VaR}(\mathrm{z})_{\mathrm{q}}
$$


where $\hat{\sigma}_{\mathrm{t}}=\sqrt{\hat{\alpha}_{0}+\hat{\alpha}_{1}\left(\left|\hat{\varepsilon}_{\mathrm{t}-1}\right|+\hat{\gamma}_{1} \hat{\varepsilon}_{\mathrm{t}-1}\right)^{2}+\hat{\beta}_{1} \hat{\sigma}_{\mathrm{t}-1}^{2}}$, and $\operatorname{VaR}(\mathrm{z})_{\mathrm{q}}$ is the qth quantile of the standard normal distribution. The out-of-sample VaR for a k-period time horizon is computed as

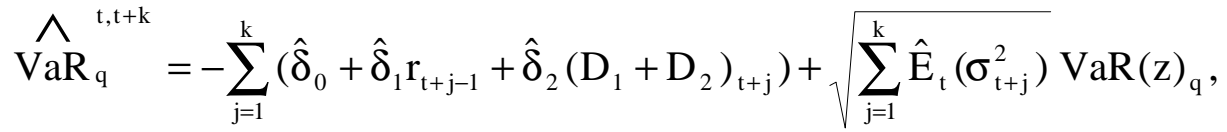

where $\hat{\mathrm{E}}_{\mathrm{t}}\left(\sigma_{\mathrm{t}+\mathrm{j}}^{2}\right)$ is given by expression (16) evaluated at the parameter estimates.

VaR estimates are similar, although the Latin America model tends to be more conservative. For in-sample VaR, the percentage of times the actual loss exceeds the 95\%$\mathrm{VaR}$ is 4.14 for the Latin America model, and 4.72 for the Europe model. Out of sample, the gap between the potential loss at the 95 percent confidence level given by the two models widens as the time horizon increases. This is a consequence of the fact that the unconditional variance yielded by the Latin America model is lower than that yielded by the Europe model.

From the above, we conclude that Latin America is nearly as good a predictor of the performance of North America as it is Europe. Or put another way, spillovers from each region to North America are close in magnitude.

\section{Conclusions}

International transmission of stock market returns and volatility in international financial markets has become an important research area in finance in the past few years. Different econometric techniques have been used to quantify such spillovers (e.g., multivariate GARCH models, vector autorregresive regressions (VAR), extreme value theory). In this article, we use wavelet analysis, a relatively new statistical technique that has started to become popular in finance. Wavelet analysis allows for the decomposition of time series data into orthogonal components with different frequencies. This makes it possible to quantify correlations between markets at different time horizons.

The focus of this article was the quantification of price spillovers in stock markets at different time scales. We looked at eight equity indices that comprise the G7 countries, Europe, Eastern Europe and the Middle East, Latin America, North America, Emerging Asia, the Pacific region, and the Emerging Far East for the period 1990-2002.

Our estimation results show evidence of price spillovers from the G7 countries to Europe, Eastern Europe and the Middle East, Emerging Asia, Europe, Latin America, and North America. However, price spillovers of these regions to the G7 countries are weaker at different time scales. Similarly, we find price spillovers from North America to Latin America, Emerging Asia, the Far East, and the Pacific region, and from both Europe and Latin America to North America. Our results are robust to the existence of asymmetric GARCH-effects and serial correlation in returns. 


\section{References}

Bruce A. and H. Gao (1996), Applied Wavelet Analysis with S-Plus. Springer-Verlag.

Forbes, K. and R. Rigobon (2002), "No Contagion, only Interdependence: Measuring Stock Market Comovements," The Journal of Finance 57(5), 2223-2261.

Gençay R., B. Whitcher, and F. Selçuk (2002), "Multi-scale systematic risk," National Centre of Competence (NCCR) in Research Financial Valuation and Risk Management Working Paper No. 43.

Henttschel, L. (1995), "All in the family: nesting symmetric and asymmetric GARCH models." Journal of Financial Economics 39, 71-104.

Karolyi, G.A. (1995), “A Multivariate GARCH model of International Transmissions of Stock Returns and Volatility: The Case of the U.S. and Canada," Journal of Business and Economics Statistics 13(1), 11-25.

(2003), "Does International Financial Contagion Really Exist?" International Finance 6(2), 179-199.

and R. Stulz (1996), "Why Do Markets Move Together? An Investigation of the U.S.-Japan Stock Comovements," The Journal of Finance 51(3), Papers and Proceedings of the Fifty-Sixth Annual Meeting of the American Finance Association, 951986.

Lee, Hahn Shik (2001a), "Price and Volatility Spillovers in Stock Markets: A Wavelet Analysis". Manuscript presented at the 2001 Australasian Meeting of the Econometric Society.

(2001b), "Recent Advances in Wavelet Methods for Economic Time Series," Journal of Economic Theory and Econometrics 7(1), 43-65.

Lin, W., R.F. Engle and T. Ito (1994), "Do Bulls and Bears Move Across Borders? International Transmission of Stock Prices and Volatility," Review of Financial Studies 7(3), 507-538.

Mckenzie, M., and H. Mitchell (2002), "Generalized asymmetric power ARCH modelling of exchange rate volatility." Applied Financial Economics 12, 555-564.

Ng, A. (2000), "Volatility Spillovers from Japan and the U.S. to the Pacific Basin," Journal of International Money and Finance 12, 207-233.

Norsworthy J. D. Li and R. Gorener (2000) "Wavelet-Based Analysis of Time Series: An Export from Engineering to Finance." Manuscript presented at the 2000 IEEE International Engineering Management Society Conference. 
Percival, D. and A. Walden (2000), Wavelets Analysis for Time Series Analysis. Cambridge University Press, Cambridge, U.K.

Poon, S., M. Rockinger, and J. Tawn (2003), "Modeling Extreme-Value Dependence in International Stock Markets," Statistica Sinica. 13(4), 929-953.

Ramsey J., and C. Lampart (1998), "The Decomposition of Economic Relationships by Time Scale Using Wavelets: Expenditure and Income," Studies in Nonlinear Dynamics \& Econometrics 3(1), 23-42.

Worthington A. and H. Higgs (2004), "Transmission of equity returns and volatility in Asian developed and emerging markets: a multivariate GARCH analysis," International Journal of Finance and Economics 9(1), 71-80. 
Table 1 Descriptive Statistics of Returns on Selected Morgan Stanley Stock Indices: 1990-2002

\begin{tabular}{ccccccccc}
\hline & $\begin{array}{c}\text { Latin } \\
\text { America }\end{array}$ & $\begin{array}{c}\text { North } \\
\text { America }\end{array}$ & $\begin{array}{c}\text { Emerging } \\
\text { Asia }\end{array}$ & Europe & $\begin{array}{c}\text { Europe \& } \\
\text { Middle East }\end{array}$ & Pacific & $\begin{array}{c}\text { Emerging } \\
\text { Far East }\end{array}$ & G7 \\
\hline Observations & 3,362 & 3,362 & 3,362 & 3,362 & 3,362 & 3,362 & 3,362 & 3,362 \\
Mean & 0.000 & 0.000 & 0.000 & 0.000 & 0.000 & 0.000 & 0.000 & 0.000 \\
Median & 0.001 & 0.000 & 0.000 & 0.001 & 0.000 & 0.000 & 0.000 & 0.000 \\
Std. dev. & 0.016 & 0.010 & 0.013 & 0.010 & 0.015 & 0.014 & 0.014 & 0.009 \\
25\%-quantile & -0.007 & -0.004 & -0.006 & -0.005 & -0.007 & -0.007 & -0.008 & -0.004 \\
50\%-quantile & 0.001 & 0.000 & 0.000 & 0.001 & 0.000 & 0.000 & 0.000 & 0.000 \\
75\%-quantile & 0.009 & 0.005 & 0.006 & 0.006 & 0.008 & 0.007 & 0.007 & 0.005 \\
Minimum & -0.145 & -0.069 & -0.075 & -0.085 & -0.102 & -0.078 & -0.081 & -0.048 \\
Maximum & 0.135 & 0.055 & 0.076 & 0.053 & 0.083 & 0.108 & 0.113 & 0.047 \\
Jarque Bera test & $1,191.2$ & 250.2 & 285.4 & 298.2 & 316.7 & 314.5 & 291.3 & 137.1 \\
P-value & 0.00 & 0.00 & 0.00 & 0.00 & 0.00 & 0.00 & 0.00 & 0.00 \\
\hline
\end{tabular}

Notes: (1) Figures are daily and measured in US dollars, and were obtained from Bloomberg. (2) The Latin America index includes Argentina, Brazil, Chile, Colombia, Mexico, Peru, and Venezuela; the North America index includes Canada and the United States; the Emerging Asia index includes China, India, Indonesia, Korea, Malaysia, Pakistan, Philippines, Taiwan, and Thailand; the Europe index includes Austria, Belgium, Denmark, Finland, France, Germany, Greece, Ireland, Italy, Luxembourg, Netherlands, Norway, Portugal, Spain, Sweden, and the United Kingdom; the Europe and Middle East index includes the Czech Republic, Hungary, Israel, Jordan, Poland, Russia, and Turkey; the Pacific index includes Australia, Hong Kong, Japan, New Zealand, and Singapore; the Emerging Far East index includes China, Indonesia, Korea, Malaysia, Philippines, Taiwan, and Thailand. Finally, the G7 index includes Canada, France, Germany, Italy, Japan, the United Kingdom, and the United States. (3) The Jarque-Bera test detects whether the probability distribution function of a series departures from normality. 
Table 2 Returns Spillovers

(a) G7 regressions

\begin{tabular}{|c|c|c|c|c|c|c|}
\hline \multirow{3}{*}{ Scale } & \multicolumn{6}{|c|}{ Europe (EUR) } \\
\hline & \multicolumn{3}{|c|}{$\mathrm{R}_{\mathrm{t}}^{\mathrm{G} 7}$ on $\mathrm{R}_{\mathrm{t}}^{\mathrm{EUR}}$} & \multicolumn{3}{|c|}{$\mathrm{R}_{\mathrm{t}}^{\mathrm{EUR}}$ on $\mathrm{R}_{\mathrm{t}}^{\mathrm{G} 7}$} \\
\hline & intercept & slope & $\mathrm{R}^{2}$ & intercept & slope & $\mathrm{R}^{2}$ \\
\hline Return & $\begin{array}{c}0.000 \\
(0.926)\end{array}$ & $\begin{array}{c}0.564 \\
(0.000)\end{array}$ & 0.448 & $\begin{array}{c}0.000 \\
(0.578)\end{array}$ & $\begin{array}{c}0.795 \\
(0.000)\end{array}$ & 0.448 \\
\hline D1 & $\begin{array}{c}0.000 \\
(0.508)\end{array}$ & $\begin{array}{c}0.411 \\
(0.000)\end{array}$ & 0.104 & $\begin{array}{c}0.000 \\
(0.375)\end{array}$ & $\begin{array}{r}0.666 \\
(0.000) \\
\end{array}$ & 0.119 \\
\hline $\mathrm{D} 1+\mathrm{D} 2$ & $\begin{array}{c}0.000 \\
(0.467)\end{array}$ & $\begin{array}{c}0.501 \\
(0.012)\end{array}$ & 0.257 & $\begin{array}{c}0.000 \\
(0.330)\end{array}$ & $\begin{array}{c}0.742 \\
(0.000)\end{array}$ & 0.270 \\
\hline \multirow{3}{*}{ Scale $\quad$ Regression } & \multicolumn{6}{|c|}{ Europe and Middle East (EME) } \\
\hline & \multirow{2}{*}{\multicolumn{3}{|c|}{$\mathrm{R}_{\mathrm{t}}^{\mathrm{G} 7}$ on $\mathrm{R}_{\mathrm{t}}^{\mathrm{EME}}$}} & \multicolumn{3}{|c|}{$\mathrm{R}_{\mathrm{t}}^{\mathrm{EME}}$ on $\mathrm{R}_{\mathrm{t}}^{\mathrm{G} 7}$} \\
\hline & & & & intercept & slope & $\mathrm{R}^{2}$ \\
\hline Return & $\begin{array}{c}0.000 \\
(0.474)\end{array}$ & $\begin{array}{c}0.210 \\
(0.000)\end{array}$ & 0.125 & $\begin{array}{c}0.000 \\
(0.713)\end{array}$ & $\begin{array}{c}0.595 \\
(0.000)\end{array}$ & 0.125 \\
\hline D1 & $\begin{array}{c}0.000 \\
(0.526)\end{array}$ & $\begin{array}{c}0.136 \\
(0.000)\end{array}$ & 0.022 & $\begin{array}{c}0.000 \\
(0.901)\end{array}$ & $\begin{array}{c}0.421 \\
(0.000) \\
\end{array}$ & 0.024 \\
\hline $\mathrm{D} 1+\mathrm{D} 2$ & $\begin{array}{c}0.000 \\
(0.518)\end{array}$ & $\begin{array}{c}0.174 \\
(0.000)\end{array}$ & 0.057 & $\begin{array}{c}0.000 \\
(0.899)\end{array}$ & $\begin{array}{c}0.475 \\
(0.000)\end{array}$ & 0.055 \\
\hline \multirow{3}{*}{ Scale $\quad$ Regression } & \multicolumn{6}{|c|}{ Emerging Asia (EA) } \\
\hline & \multicolumn{3}{|c|}{$\mathrm{R}_{\mathrm{t}}^{\mathrm{G} 7}$ on $\mathrm{R}_{\mathrm{t}}^{\mathrm{EA}}$} & \multicolumn{3}{|c|}{$\mathrm{R}_{\mathrm{t}}^{\mathrm{EA}}$ on $\mathrm{R}_{\mathrm{t}-1}^{\mathrm{G} 7}$} \\
\hline & intercept & slope & $\mathrm{R}^{2}$ & intercept & slope & $\mathrm{R}^{--}$ \\
\hline Return & $\begin{array}{c}0.000 \\
(0.418)\end{array}$ & $\begin{array}{c}0.179 \\
(0.000)\end{array}$ & 0.066 & $\begin{array}{c}0.000 \\
(0.369)\end{array}$ & $\begin{array}{c}0.527 \\
(0.000)\end{array}$ & 0.132 \\
\hline D1 & $\begin{array}{c}0.000 \\
(0.530)\end{array}$ & $\begin{array}{c}0.020 \\
(0.315)\end{array}$ & 0.000 & $\begin{array}{c}0.000 \\
(0.538)\end{array}$ & $\begin{array}{c}0.313 \\
(0.000) \\
\end{array}$ & 0.018 \\
\hline $\mathrm{D} 1+\mathrm{D} 2$ & $\begin{array}{c}0.000 \\
(0.527) \\
\end{array}$ & $\begin{array}{c}0.111 \\
(0.000) \\
\end{array}$ & 0.017 & $\begin{array}{c}0.000 \\
(0.531) \\
\end{array}$ & $\begin{array}{c}0.384 \\
(0.000) \\
\end{array}$ & 0.049 \\
\hline \multirow{3}{*}{ Scale $\quad$ Regression } & \multicolumn{6}{|c|}{ Emerging Far East $(\mathrm{FE})$} \\
\hline & \multicolumn{3}{|c|}{$R_{t}^{\mathrm{G} 7}$ on $R_{t}{ }^{F E}$} & \multicolumn{3}{|c|}{$\mathrm{R}_{\mathrm{t}}^{\mathrm{FE}}$ on $\mathrm{R}_{\mathrm{t}-1}^{\mathrm{G} 7}$} \\
\hline & intercept & slope & $\mathrm{R}^{2}$ & intercept & slope & $\mathrm{R}^{2}$ \\
\hline Return & $\begin{array}{c}0.000 \\
(0.163)\end{array}$ & $\begin{array}{c}0.327 \\
(0.000)\end{array}$ & 0.288 & $\begin{array}{c}0.000 \\
(0.222)\end{array}$ & $\begin{array}{c}0.429 \\
(0.000)\end{array}$ & 0.068 \\
\hline D1 & $\begin{array}{c}0.000 \\
(0.514)\end{array}$ & $\begin{array}{c}0.250 \\
(0.000)\end{array}$ & 0.077 & $\begin{array}{c}0.000 \\
(0.308)\end{array}$ & $\begin{array}{l}-0.196 \\
(0.000)\end{array}$ & 0.005 \\
\hline $\mathrm{D} 1+\mathrm{D} 2$ & $\begin{array}{c}0.000 \\
(0.493) \\
\end{array}$ & $\begin{array}{c}0.286 \\
(0.000) \\
\end{array}$ & 0.163 & $\begin{array}{c}0.000 \\
(0.308) \\
\end{array}$ & $\begin{array}{c}0.178 \\
(0.000) \\
\end{array}$ & 0.008 \\
\hline \multirow{3}{*}{ Scale } & \multicolumn{6}{|c|}{ Latin America (LA) } \\
\hline & \multicolumn{3}{|c|}{$\mathrm{R}_{\mathrm{t}}^{\mathrm{G} 7}$ on $\mathrm{R}_{\mathrm{t}-1}^{\mathrm{LA}}$} & \multicolumn{3}{|c|}{$\mathrm{R}_{\mathrm{t}}^{\mathrm{LA}}$ on $\mathrm{R}_{\mathrm{t}}^{\mathrm{G} 7}$} \\
\hline & intercept & slope & $\mathrm{R}^{2}$ & intercept & slope & $\mathrm{R}^{2}$ \\
\hline Return & $\begin{array}{c}0.000 \\
(0.577)\end{array}$ & $\begin{array}{c}0.049 \\
(0.000)\end{array}$ & 0.008 & $\begin{array}{c}0.000 \\
(0.470)\end{array}$ & $\begin{array}{c}0.849 \\
(0.000) \\
\end{array}$ & 0.206 \\
\hline D1 & $\begin{array}{c}0.000 \\
(0.521)\end{array}$ & $\begin{array}{l}-0.122 \\
(0.000)\end{array}$ & 0.020 & $\begin{array}{c}0.000 \\
(0.338)\end{array}$ & $\begin{array}{c}0.748 \\
(0.000)\end{array}$ & 0.061 \\
\hline $\mathrm{D} 1+\mathrm{D} 2$ & $\begin{array}{c}0.000 \\
(0.521)\end{array}$ & $\begin{array}{l}-0.029 \\
(0.012)\end{array}$ & 0.002 & $\begin{array}{c}0.000 \\
(0.318)\end{array}$ & $\begin{array}{c}0.825 \\
(0.000)\end{array}$ & 0.135 \\
\hline
\end{tabular}




\begin{tabular}{|c|c|c|c|c|c|c|c|}
\hline \multirow{3}{*}{ Scale } & \multirow{3}{*}{ Regression } & \multicolumn{6}{|c|}{ North America (NA) } \\
\hline & & \multicolumn{3}{|c|}{$\mathrm{R}_{\mathrm{t}}^{\mathrm{G} 7}$ on $\mathrm{R}_{\mathrm{t}}^{\mathrm{NA}}$} & \multicolumn{3}{|c|}{$R_{t}{ }^{N A}$ on $R_{t}{ }^{G 7}$} \\
\hline & & intercept & slope & $\mathrm{R}^{2}$ & intercept & slope & $\mathrm{R}^{2}$ \\
\hline & Return & $\begin{array}{l}-0.000 \\
(0.251)\end{array}$ & $\begin{array}{c}0.710 \\
(0.000)\end{array}$ & 0.691 & $\begin{array}{c}0.000 \\
(0.072)\end{array}$ & $\begin{array}{r}0.973 \\
(0.000)\end{array}$ & 0.691 \\
\hline & D1 & $\begin{array}{c}0.000 \\
(0.473)\end{array}$ & $\begin{array}{r}0.616 \\
(0.000)\end{array}$ & 0.235 & $\begin{array}{c}0.000 \\
(0.073)\end{array}$ & $\begin{array}{c}1.001 \\
(0.000)\end{array}$ & 0.280 \\
\hline & $\mathrm{D} 1+\mathrm{D} 2$ & $\begin{array}{c}0.000 \\
(0.393)\end{array}$ & $\begin{array}{c}0.671 \\
(0.000)\end{array}$ & 0.462 & $\begin{array}{c}0.000 \\
(0.032)\end{array}$ & $\begin{array}{r}0.994 \\
(0.000)\end{array}$ & 0.499 \\
\hline
\end{tabular}

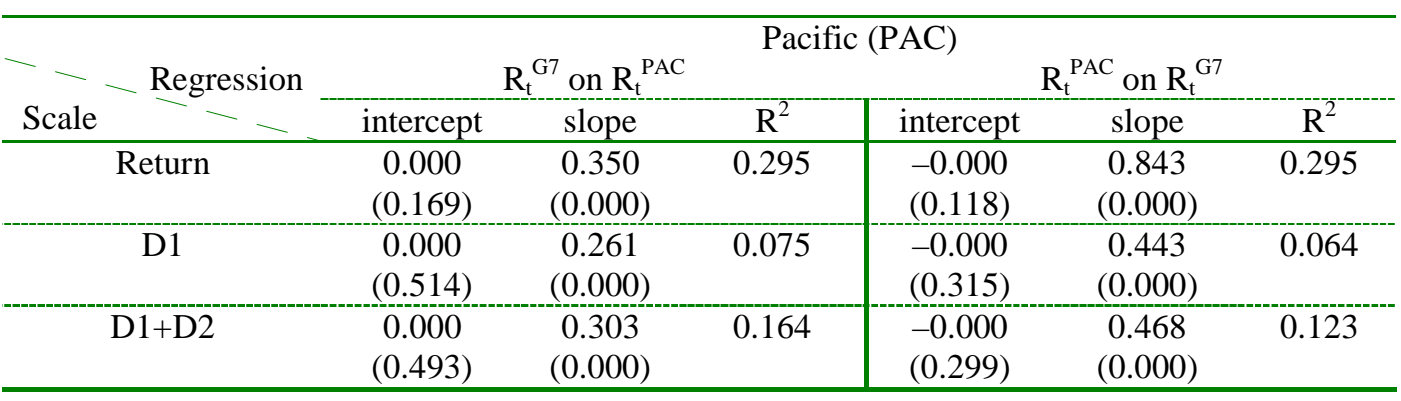

(b) Pacific regressions

\begin{tabular}{|c|c|c|c|c|c|c|c|}
\hline \multirow{3}{*}{ Scale } & \multirow{3}{*}{ Regression } & \multicolumn{6}{|c|}{ Emerging Asia } \\
\hline & & \multicolumn{3}{|c|}{$\mathrm{R}_{\mathrm{t}}^{\mathrm{PAC}}$ on $\mathrm{R}_{\mathrm{t}}^{\mathrm{EA}}$} & \multicolumn{3}{|c|}{$R_{t}^{E A}$ on $R_{t}^{\text {PAC }}$} \\
\hline & & intercept & slope & $\mathrm{R}^{2}$ & intercept & slope & $\mathrm{R}^{2}$ \\
\hline & Return & $\begin{array}{c}0.000 \\
(0.428)\end{array}$ & $\begin{array}{c}0.445 \\
(0.000)\end{array}$ & 0.173 & $\begin{array}{c}0.000 \\
(0.824)\end{array}$ & $\begin{array}{r}0.389 \\
(0.000)\end{array}$ & 0.173 \\
\hline & D1 & $\begin{array}{c}0.000 \\
(0.315)\end{array}$ & $\begin{array}{c}0.443 \\
(0.000)\end{array}$ & 0.064 & $\begin{array}{c}0.000 \\
(0.533)\end{array}$ & $\begin{array}{r}0.316 \\
(0.000) \\
\end{array}$ & 0.052 \\
\hline & $\mathrm{D} 1+\mathrm{D} 2$ & $\begin{array}{c}0.000 \\
(0.527)\end{array}$ & $\begin{array}{c}0.468 \\
(0.000)\end{array}$ & 0.123 & $\begin{array}{c}0.000 \\
(0.521)\end{array}$ & $\begin{array}{c}0.355 \\
(0.000)\end{array}$ & 0.107 \\
\hline
\end{tabular}

\begin{tabular}{|c|c|c|c|c|c|c|}
\hline \multirow{3}{*}{ Scale $\quad$ Regression } & \multicolumn{6}{|c|}{ Europe } \\
\hline & \multicolumn{3}{|c|}{$\mathrm{R}_{\mathrm{t}}^{\mathrm{PAC}}$ on $\mathrm{R}_{\mathrm{t}-1}^{\mathrm{EUR}}$} & \multicolumn{3}{|c|}{$\mathrm{R}_{\mathrm{t}}^{\mathrm{EUR}}$ on $\mathrm{R}_{\mathrm{t}}^{\mathrm{PAC}}$} \\
\hline & intercept & slope & $\mathrm{R}^{2}$ & intercept & slope & $\mathrm{R}^{2}$ \\
\hline Return & $\begin{array}{c}0.000 \\
(0.237)\end{array}$ & $\begin{array}{c}0.300 \\
(0.000)\end{array}$ & 0.053 & $\begin{array}{c}0.000 \\
(0.229)\end{array}$ & $\begin{array}{c}0.243 \\
(0.000)\end{array}$ & 0.101 \\
\hline D1 & $\begin{array}{c}0.000 \\
(0.335)\end{array}$ & $\begin{array}{c}0.045 \\
(0.187)\end{array}$ & 0.000 & $\begin{array}{c}0.000 \\
(0.400)\end{array}$ & $\begin{array}{c}0.166 \\
(0.000)\end{array}$ & 0.021 \\
\hline $\mathrm{D} 1+\mathrm{D} 2$ & $\begin{array}{c}0.000 \\
(0.333)\end{array}$ & $\begin{array}{c}0.174 \\
(0.000)\end{array}$ & 0.013 & $\begin{array}{c}0.000 \\
(0.393)\end{array}$ & $\begin{array}{r}0.199 \\
(0.000)\end{array}$ & 0.050 \\
\hline
\end{tabular}

\begin{tabular}{|c|c|c|c|c|c|c|}
\hline \multirow{3}{*}{ Scale Regr } & \multicolumn{6}{|c|}{$\begin{array}{l}\text { Europe and Middle East }\end{array}$} \\
\hline & \multicolumn{3}{|c|}{$\mathrm{R}_{\mathrm{t}}^{\mathrm{PAC}}$ on $\mathrm{R}_{\mathrm{t}-1}^{\mathrm{EME}}$} & \multicolumn{3}{|c|}{$\mathrm{R}_{\mathrm{t}}^{\mathrm{EME}}$ on $\mathrm{R}_{\mathrm{t}}^{\text {PAC }}$} \\
\hline & intercept & slope & $\mathrm{R}^{2}$ & intercept & slope & $\mathrm{R}^{2}$ \\
\hline Return & $\begin{array}{c}0.000 \\
(0.339)\end{array}$ & $\begin{array}{c}0.072 \\
(0.000)\end{array}$ & 0.006 & $\begin{array}{c}0.000 \\
(0.892)\end{array}$ & $\begin{array}{c}0.282 \\
(0.000) \\
\end{array}$ & 0.068 \\
\hline D1 & $\begin{array}{c}0.000 \\
(0.335)\end{array}$ & $\begin{array}{l}-0.084 \\
(0.001)\end{array}$ & 0.003 & $\begin{array}{c}0.000 \\
(0.902)\end{array}$ & $\begin{array}{c}0.232 \\
(0.000)\end{array}$ & 0.021 \\
\hline $\mathrm{D} 1+\mathrm{D} 2$ & $\begin{array}{c}0.000 \\
(0.333)\end{array}$ & $\begin{array}{l}-0.011 \\
(0.565)\end{array}$ & 0.000 & $\begin{array}{c}0.000 \\
(0.901)\end{array}$ & $\begin{array}{c}0.242 \\
(0.000)\end{array}$ & 0.037 \\
\hline
\end{tabular}




\begin{tabular}{|c|c|c|c|c|c|c|c|}
\hline \multirow{3}{*}{\multicolumn{2}{|c|}{ Scale $\quad$ Regression }} & \multicolumn{6}{|c|}{ Latin America } \\
\hline & & \multicolumn{3}{|c|}{$\mathrm{R}_{\mathrm{t}}^{\mathrm{PAC}}$ on $\mathrm{R}_{\mathrm{t}-1}^{\mathrm{LA}}$} & \multicolumn{3}{|c|}{$R_{t}{ }^{L A}$ on $R_{t}{ }^{P A C}$} \\
\hline & & intercept & slope & $\mathrm{R}^{2}$ & intercept & slope & $\mathrm{R}^{2}$ \\
\hline & Return & $\begin{array}{c}0.000 \\
(0.250)\end{array}$ & $\begin{array}{c}0.150 \\
(0.000)\end{array}$ & 0.033 & $\begin{array}{c}0.000 \\
(0.281)\end{array}$ & $\begin{array}{c}0.172 \\
(0.000)\end{array}$ & 0.020 \\
\hline & D1 & $\begin{array}{c}0.000 \\
(0.336)\end{array}$ & $\begin{array}{c}0.103 \\
(0.000)\end{array}$ & 0.006 & $\begin{array}{c}0.000 \\
(0.353)\end{array}$ & $\begin{array}{r}0.004 \\
(0.889)\end{array}$ & 0.000 \\
\hline & $\mathrm{D} 1+\mathrm{D} 2$ & $\begin{array}{c}0.000 \\
(0.331)\end{array}$ & $\begin{array}{c}0.139 \\
(0.000)\end{array}$ & 0.018 & $\begin{array}{c}0.000 \\
(0.352)\end{array}$ & $\begin{array}{c}0.106 \\
(0.000)\end{array}$ & 0.006 \\
\hline
\end{tabular}

\begin{tabular}{|c|c|c|c|c|c|c|c|}
\hline \multirow{3}{*}{\multicolumn{2}{|c|}{ Scale $\quad$ Regression }} & \multicolumn{6}{|c|}{ North America } \\
\hline & & \multicolumn{3}{|c|}{$\mathrm{R}_{\mathrm{t}}^{\mathrm{PAC}}$ on $\mathrm{R}_{\mathrm{t}-1}^{\mathrm{NA}}$} & \multicolumn{3}{|c|}{$\mathrm{R}_{\mathrm{t}}^{\mathrm{NA}}$ on $\mathrm{R}_{\mathrm{t}}^{\mathrm{PAC}}$} \\
\hline & & intercept & slope & $\mathrm{R}^{2}$ & intercept & slope & $\mathrm{R}^{2}$ \\
\hline & Return & $\begin{array}{c}0.000 \\
(0.147)\end{array}$ & $\begin{array}{c}0.374 \\
(0.000)\end{array}$ & 0.080 & $\begin{array}{c}0.000 \\
(0.102)\end{array}$ & $\begin{array}{c}0.080 \\
(0.000)\end{array}$ & 0.011 \\
\hline & D1 & $\begin{array}{c}0.000 \\
(0.331)\end{array}$ & $\begin{array}{c}0.259 \\
(0.000)\end{array}$ & 0.017 & $\begin{array}{c}0.000 \\
(0.128)\end{array}$ & $\begin{array}{l}-0.044 \\
(0.023)\end{array}$ & 0.002 \\
\hline & $\mathrm{D} 1+\mathrm{D} 2$ & $\begin{array}{c}0.000 \\
(0.325)\end{array}$ & $\begin{array}{c}0.323 \\
(0.000)\end{array}$ & 0.044 & $\begin{array}{c}0.000 \\
(0.128)\end{array}$ & $\begin{array}{c}0.020 \\
(0.188)\end{array}$ & 0.001 \\
\hline
\end{tabular}

(c) Latin America regressions

\begin{tabular}{|c|c|c|c|c|c|c|c|}
\hline \multirow{3}{*}{ Scale } & \multirow{3}{*}{ Regression } & \multicolumn{6}{|c|}{ Emerging Asia } \\
\hline & & \multicolumn{3}{|c|}{$\mathrm{R}_{\mathrm{t}}^{\mathrm{LA}}$ on $\mathrm{R}_{\mathrm{t}}^{\mathrm{EA}}$} & \multicolumn{3}{|c|}{$\mathrm{R}_{\mathrm{t}}^{\mathrm{EA}}$ on $\mathrm{R}_{\mathrm{t}-1}^{\mathrm{LA}}$} \\
\hline & & intercept & slope & $\mathrm{R}^{2}$ & intercept & slope & $\mathrm{R}^{2}$ \\
\hline & Return & $\begin{array}{c}0.000 \\
(0.289)\end{array}$ & $\begin{array}{c}0.242 \\
(0.000)\end{array}$ & 0.035 & $\begin{array}{c}0.000 \\
(0.375)\end{array}$ & $\begin{array}{r}0.203 \\
(0.000)\end{array}$ & 0.069 \\
\hline & D1 & $\begin{array}{c}0.000 \\
(0.353)\end{array}$ & $\begin{array}{c}0.037 \\
(0.308)\end{array}$ & 0.000 & $\begin{array}{c}0.000 \\
(0.538)\end{array}$ & $\begin{array}{r}0.130 \\
(0.000) \\
\end{array}$ & 0.019 \\
\hline & $\mathrm{D} 1+\mathrm{D} 2$ & $\begin{array}{c}0.000 \\
(0.351)\end{array}$ & $\begin{array}{c}0.143 \\
(0.000)\end{array}$ & 0.008 & $\begin{array}{c}0.000 \\
(0.535)\end{array}$ & $\begin{array}{c}0.148 \\
(0.000)\end{array}$ & 0.024 \\
\hline
\end{tabular}

\begin{tabular}{|c|c|c|c|c|c|c|}
\hline \multirow{3}{*}{ Scale $\quad$ Regression } & \multicolumn{6}{|c|}{ Europe } \\
\hline & \multicolumn{3}{|c|}{$\mathrm{R}_{\mathrm{t}}^{\mathrm{LA}}$ on $\mathrm{R}_{\mathrm{t}}^{\mathrm{EUR}}$} & \multicolumn{3}{|c|}{$\mathrm{R}_{\mathrm{t}}^{\mathrm{EUR}}$ on $\mathrm{R}_{\mathrm{t}-1}^{\mathrm{LA}}$} \\
\hline & intercept & slope & $\mathrm{R}^{2}$ & intercept & slope & $\mathrm{R}^{2}$ \\
\hline Return & $\begin{array}{c}0.000 \\
(0.492)\end{array}$ & $\begin{array}{c}0.532 \\
(0.000)\end{array}$ & 0.114 & $\begin{array}{c}0.000 \\
(0.490)\end{array}$ & $\begin{array}{c}0.106 \\
(0.000)\end{array}$ & 0.028 \\
\hline D1 & $\begin{array}{c}0.000 \\
(0.349)\end{array}$ & $\begin{array}{c}0.327 \\
(0.000)\end{array}$ & 0.019 & $\begin{array}{c}0.000 \\
(0.403)\end{array}$ & $\begin{array}{l}-0.029 \\
(0.060)\end{array}$ & 0.095 \\
\hline $\mathrm{D} 1+\mathrm{D} 2$ & $\begin{array}{c}0.000 \\
(0.338)\end{array}$ & $\begin{array}{c}0.452 \\
(0.000)\end{array}$ & 0.060 & $\begin{array}{c}0.000 \\
(0.402)\end{array}$ & $\begin{array}{r}0.046 \\
(0.000)\end{array}$ & 0.004 \\
\hline
\end{tabular}

\begin{tabular}{|c|c|c|c|c|c|c|}
\hline \multirow{3}{*}{ Scale Regression } & \multicolumn{6}{|c|}{ Europe and Middle East } \\
\hline & \multicolumn{3}{|c|}{$\mathrm{R}_{\mathrm{t}}^{\mathrm{LA}}$ on $\mathrm{R}_{\mathrm{t}}^{\mathrm{EME}}$} & \multicolumn{3}{|c|}{$\mathrm{R}_{\mathrm{t}}^{\mathrm{EME}}$ on $\mathrm{R}_{\mathrm{t}-1}^{\mathrm{LA}}$} \\
\hline & intercept & slope & $\mathrm{R}^{2}$ & intercept & slope & $\mathrm{R}^{2}$ \\
\hline Return & $\begin{array}{c}0.000 \\
(0.328)\end{array}$ & $\begin{array}{c}0.242 \\
(0.000)\end{array}$ & 0.048 & $\begin{array}{c}0.000 \\
(0.737)\end{array}$ & $\begin{array}{c}0.177 \\
(0.000)\end{array}$ & 0.038 \\
\hline D1 & $\begin{array}{c}0.000 \\
(0.352)\end{array}$ & $\begin{array}{c}0.115 \\
(0.000)\end{array}$ & 0.005 & $\begin{array}{c}0.000 \\
(0.883)\end{array}$ & $\begin{array}{c}0.047 \\
(0.060)\end{array}$ & 0.001 \\
\hline $\mathrm{D} 1+\mathrm{D} 2$ & $\begin{array}{l}0.000 \\
(0.349)\end{array}$ & $\begin{array}{c}0.171 \\
(0.000)\end{array}$ & 0.016 & $\begin{array}{c}0.000 \\
(0.882)\end{array}$ & $\begin{array}{c}0.096 \\
(0.000)\end{array}$ & 0.008 \\
\hline
\end{tabular}




\begin{tabular}{|c|c|c|c|c|c|c|}
\hline \multirow{3}{*}{ Scale } & \multicolumn{6}{|c|}{ Emerging Far East } \\
\hline & \multicolumn{3}{|c|}{$\mathrm{R}_{\mathrm{t}}^{\mathrm{LA}}$ on $\mathrm{R}_{\mathrm{t}}^{\mathrm{FE}}$} & \multicolumn{3}{|c|}{$\mathrm{R}_{\mathrm{t}}^{\mathrm{FE}}$ on $\mathrm{R}_{\mathrm{t}-1}^{\mathrm{LA}}$} \\
\hline & intercept & slope & $\mathrm{R}^{2}$ & intercept & slope & $\mathrm{R}^{2-}$ \\
\hline Return & $\begin{array}{c}0.000 \\
(0.282)\end{array}$ & $\begin{array}{c}0.154 \\
(0.000)\end{array}$ & 0.018 & $\begin{array}{c}0.000 \\
(0.234)\end{array}$ & $\begin{array}{c}0.148 \\
(0.000)\end{array}$ & 0.028 \\
\hline D1 & $\begin{array}{c}0.000 \\
(0.353)\end{array}$ & $\begin{array}{c}0.003 \\
(0.907)\end{array}$ & 0.000 & $\begin{array}{c}0.000 \\
(0.308)\end{array}$ & $\begin{array}{c}0.102 \\
(0.000) \\
\end{array}$ & 0.005 \\
\hline $\mathrm{D} 1+\mathrm{D} 2$ & $\begin{array}{c}0.000 \\
(0.352)\end{array}$ & $\begin{array}{c}0.096 \\
(0.000)\end{array}$ & 0.005 & $\begin{array}{c}0.000 \\
(0.305)\end{array}$ & $\begin{array}{r}0.137 \\
(0.000) \\
\end{array}$ & 0.016 \\
\hline Regression & \multicolumn{4}{|c|}{ North America } & \multicolumn{2}{|c|}{${ }_{t}^{N A}$ on $R_{t}^{L A}$} \\
\hline Scale $>$ & intercept & slope & $\mathrm{R}^{2}$ & intercept & slope & $\mathrm{R}^{2}$ \\
\hline Return & $\begin{array}{c}0.000 \\
(0.794)\end{array}$ & $\begin{array}{c}0.729 \\
(0.000)\end{array}$ & 0.209 & $\begin{array}{c}0.000 \\
(0.217)\end{array}$ & $\begin{array}{r}0.286 \\
(0.000)\end{array}$ & 0.209 \\
\hline D1 & $\begin{array}{c}0.000 \\
(0.336)\end{array}$ & $\begin{array}{c}0.629 \\
(0.000)\end{array}$ & 0.070 & $\begin{array}{c}0.000 \\
(0.112)\end{array}$ & $\begin{array}{r}0.286 \\
(0.000) \\
\end{array}$ & 0.081 \\
\hline $\mathrm{D} 1+\mathrm{D} 2$ & $\begin{array}{c}0.000 \\
(0.318)\end{array}$ & $\begin{array}{c}0.682 \\
(0.000)\end{array}$ & 0.136 & $\begin{array}{c}0.000 \\
(0.098)\end{array}$ & $\begin{array}{c}0.305 \\
(0.000)\end{array}$ & 0.155 \\
\hline
\end{tabular}

(d) North America regressions

\begin{tabular}{|c|c|c|c|c|c|c|}
\hline \multirow{3}{*}{ Scale $\quad$ Regression } & \multicolumn{6}{|c|}{ Emerging Asia } \\
\hline & \multicolumn{3}{|c|}{$\mathrm{R}_{\mathrm{t}}^{\mathrm{NA}}$ on $\mathrm{R}_{\mathrm{t}}^{\mathrm{EA}}$} & \multicolumn{3}{|c|}{$\mathrm{R}_{\mathrm{t}}^{\mathrm{EA}}$ on $\mathrm{R}_{\mathrm{t}-1}^{\mathrm{NA}}$} \\
\hline & intercept & slope & $\mathrm{R}^{2}$ & intercept & slope & $\mathrm{R}^{2}$ \\
\hline Return & $\begin{array}{c}0.000 \\
(0.110)\end{array}$ & $\begin{array}{c}0.088 \\
(0.000)\end{array}$ & 0.012 & $\begin{array}{c}0.000 \\
(0.203)\end{array}$ & $\begin{array}{c}0.463 \\
(0.000)\end{array}$ & 0.140 \\
\hline D1 & $\begin{array}{c}0.000 \\
(0.125)\end{array}$ & $\begin{array}{l}-0.148 \\
(0.000)\end{array}$ & 0.012 & $\begin{array}{c}0.000 \\
(0.533)\end{array}$ & $\begin{array}{c}0.350 \\
(0.000)\end{array}$ & 0.036 \\
\hline $\mathrm{D} 1+\mathrm{D} 2$ & $\begin{array}{c}0.000 \\
(0.128) \\
\end{array}$ & $\begin{array}{l}-0.009 \\
(0.616)\end{array}$ & 0.000 & $\begin{array}{c}0.000 \\
(0.527)\end{array}$ & $\begin{array}{c}0.376 \\
(0.000)\end{array}$ & 0.069 \\
\hline \multirow{2}{*}{ Scale Regression } & \multicolumn{4}{|c|}{ Europe } & \multicolumn{2}{|c|}{$\mathrm{R}_{\mathrm{t}}^{\mathrm{EUR}}$ on $\mathrm{R}_{\mathrm{t}-1}^{\mathrm{NA}}$} \\
\hline & intercept & slope & $\mathrm{R}^{2}$ & intercept & slope & $\mathrm{R}^{2}$ \\
\hline Return & $\begin{array}{c}0.000 \\
(0.193)\end{array}$ & $\begin{array}{c}0.385 \\
(0.000)\end{array}$ & 0.152 & $\begin{array}{c}0.000 \\
(0.716)\end{array}$ & $\begin{array}{c}0.328 \\
(0.000) \\
\end{array}$ & 0.104 \\
\hline D1 & $\begin{array}{c}0.000 \\
(0.125)\end{array}$ & $\begin{array}{r}0.157 \\
(0.000)\end{array}$ & 0.011 & $\begin{array}{c}0.000 \\
(0.403)\end{array}$ & $\begin{array}{c}0.066 \\
(0.011)\end{array}$ & 0.001 \\
\hline $\mathrm{D} 1+\mathrm{D} 2$ & $\begin{array}{c}0.000 \\
(0.333) \\
\end{array}$ & $\begin{array}{c}0.293 \\
(0.000) \\
\end{array}$ & 0.064 & $\begin{array}{c}0.000 \\
(0.395)\end{array}$ & $\begin{array}{c}0.300 \\
(0.000)\end{array}$ & 0.032 \\
\hline \multirow{2}{*}{ Scale } & \multicolumn{5}{|c|}{ Europe and Middle East } & $\mathrm{R}_{\mathrm{t}}^{\mathrm{EME}}$ on $\mathrm{R}_{\mathrm{t}-1}{ }^{\mathrm{NA}}$ \\
\hline & intercept & slope & $\mathrm{R}^{2}$ & intercept & slope & $\mathrm{R}^{--}$ \\
\hline Return & $\begin{array}{l}0.000 \\
(0.113)\end{array}$ & $\begin{array}{l}0.145 \\
(0.000)\end{array}$ & 0.044 & $\begin{array}{c}0.000 \\
(0.584)\end{array}$ & $\begin{array}{c}0.362 \\
(0.000)\end{array}$ & 0.063 \\
\hline D1 & $\begin{array}{c}0.000 \\
(0.128)\end{array}$ & $\begin{array}{c}0.045 \\
(0.017)\end{array}$ & 0.002 & $\begin{array}{c}0.000 \\
(0.883)\end{array}$ & $\begin{array}{c}0.149 \\
(0.000)\end{array}$ & 0.005 \\
\hline $\mathrm{D} 1+\mathrm{D} 2$ & $\begin{array}{c}0.000 \\
(0.125)\end{array}$ & $\begin{array}{c}0.094 \\
(0.000)\end{array}$ & 0.012 & $\begin{array}{c}0.000 \\
(0.882)\end{array}$ & $\begin{array}{c}0.241 \\
(0.000)\end{array}$ & 0.021 \\
\hline
\end{tabular}




\begin{tabular}{|c|c|c|c|c|c|c|c|}
\hline \multirow{3}{*}{\multicolumn{2}{|c|}{ Scale $\quad$ Regression }} & \multicolumn{6}{|c|}{ Emerging Far East } \\
\hline & & \multicolumn{3}{|c|}{$\mathrm{R}_{\mathrm{t}}^{\mathrm{NA}}$ on $\mathrm{R}_{\mathrm{t}}^{\mathrm{FE}}$} & \multicolumn{3}{|c|}{$\mathrm{R}_{\mathrm{t}}^{\mathrm{FE}}$ on $\mathrm{R}_{\mathrm{t}-1}{ }^{\mathrm{NA}}$} \\
\hline & & intercept & slope & $\mathrm{R}^{2}$ & intercept & slope & $\mathrm{R}^{2}$ \\
\hline & Return & $\begin{array}{c}0.000 \\
(0.102)\end{array}$ & $\begin{array}{c}0.073 \\
(0.000)\end{array}$ & 0.011 & $\begin{array}{c}0.000 \\
(0.143)\end{array}$ & $\begin{array}{c}0.366 \\
(0.000)\end{array}$ & 0.068 \\
\hline & D1 & $\begin{array}{c}0.000 \\
(0.128)\end{array}$ & $\begin{array}{l}-0.034 \\
(0.065)\end{array}$ & 0.065 & $\begin{array}{c}0.000 \\
(0.306)\end{array}$ & $\begin{array}{c}0.248 \\
(0.000)\end{array}$ & 0.014 \\
\hline & $\mathrm{D} 1+\mathrm{D} 2$ & $\begin{array}{c}0.000 \\
(0.128)\end{array}$ & $\begin{array}{c}0.022 \\
(0.132)\end{array}$ & 0.000 & $\begin{array}{c}0.000 \\
(0.300)\end{array}$ & $\begin{array}{c}0.314 \\
(0.000)\end{array}$ & 0.038 \\
\hline
\end{tabular}

\begin{tabular}{|c|c|c|c|c|c|c|}
\hline \multirow{3}{*}{ Scale Regression } & \multicolumn{6}{|c|}{ Pacific } \\
\hline & \multicolumn{3}{|c|}{$\mathrm{R}_{\mathrm{t}}^{\mathrm{NA}}$ on $\mathrm{R}_{\mathrm{t}}^{\mathrm{PAC}}$} & \multicolumn{3}{|c|}{$\mathrm{R}_{\mathrm{t}}{ }^{\mathrm{PAC}}$ on $\mathrm{R}_{\mathrm{t}-1}$ NA } \\
\hline & intercept & slope & $\mathrm{R}^{2}$ & intercept & slope & $\mathrm{R}^{2}$ \\
\hline Return & $\begin{array}{c}0.000 \\
(0.102)\end{array}$ & $\begin{array}{c}0.080 \\
(0.000)\end{array}$ & 0.011 & $\begin{array}{c}0.000 \\
(0.147)\end{array}$ & $\begin{array}{c}0.374 \\
(0.000)\end{array}$ & 0.080 \\
\hline D1 & $\begin{array}{c}0.000 \\
(0.128)\end{array}$ & $\begin{array}{l}-0.044 \\
(0.023)\end{array}$ & 0.023 & $\begin{array}{c}0.000 \\
(0.331)\end{array}$ & $\begin{array}{c}0.259 \\
(0.000)\end{array}$ & 0.017 \\
\hline $\mathrm{D} 1+\mathrm{D} 2$ & $\begin{array}{c}0.000 \\
(0.128)\end{array}$ & $\begin{array}{c}0.019 \\
(0.189)\end{array}$ & 0.189 & $\begin{array}{c}0.000 \\
(0.325)\end{array}$ & $\begin{array}{c}0.323 \\
(0.000)\end{array}$ & 0.044 \\
\hline
\end{tabular}

(e) Europe regressions

\begin{tabular}{|c|c|c|c|c|c|c|}
\hline \multirow{3}{*}{ Regression } & \multicolumn{6}{|c|}{ Emerging Asia } \\
\hline & \multicolumn{3}{|c|}{$\mathrm{R}_{\mathrm{t}}^{\mathrm{EUR}}$ on $\mathrm{R}_{\mathrm{t}}^{\mathrm{EA}}$} & \multicolumn{3}{|c|}{$\mathrm{R}_{\mathrm{t}}^{\mathrm{EA}}$ on $\mathrm{R}_{\mathrm{t}-1}{ }^{\mathrm{EUR}}$} \\
\hline & intercept & slope & $\mathrm{R}^{2}$ & intercept & slope & $\mathrm{R}^{2}$ \\
\hline Return & $\begin{array}{c}0.000 \\
(0.308)\end{array}$ & $\begin{array}{c}0.207 \\
(0.000)\end{array}$ & 0.064 & $\begin{array}{c}0.000 \\
(0.389)\end{array}$ & $\begin{array}{c}0.307 \\
(0.000)\end{array}$ & 0.071 \\
\hline D1 & $\begin{array}{c}0.000 \\
(0.403)\end{array}$ & $\begin{array}{c}0.113 \\
(0.000)\end{array}$ & 0.007 & $\begin{array}{c}0.000 \\
(0.540)\end{array}$ & $\begin{array}{c}0.110 \\
(0.000)\end{array}$ & 0.004 \\
\hline $\mathrm{D} 1+\mathrm{D} 2$ & $\begin{array}{c}0.000 \\
(0.400)\end{array}$ & $\begin{array}{c}0.143 \\
(0.000)\end{array}$ & 0.020 & $\begin{array}{c}0.000 \\
(0.538)\end{array}$ & $\begin{array}{c}0.177 \\
(0.000)\end{array}$ & 0.015 \\
\hline \multirow{2}{*}{ Regression } & \multicolumn{6}{|c|}{ Emerging Far East } \\
\hline & intercept & slope & $\mathrm{R}^{2}$ & intercept & slope & $\mathrm{R}^{2}$ \\
\hline Return & $\begin{array}{c}0.000 \\
(0.229)\end{array}$ & $\begin{array}{c}0.221 \\
(0.000)\end{array}$ & 0.229 & $\begin{array}{c}0.000 \\
(0.222)\end{array}$ & $\begin{array}{r}0.300 \\
(0.000) \\
\end{array}$ & 0.050 \\
\hline D1 & $\begin{array}{c}0.000 \\
(0.400)\end{array}$ & $\begin{array}{c}0.152 \\
(0.065)\end{array}$ & 0.020 & $\begin{array}{c}0.000 \\
(0.306)\end{array}$ & $\begin{array}{c}0.043 \\
(0.240)\end{array}$ & 0.000 \\
\hline $\mathrm{D} 1+\mathrm{D} 2$ & $\begin{array}{c}0.000 \\
(0.394)\end{array}$ & $\begin{array}{c}0.182 \\
(0.132)\end{array}$ & 0.047 & $\begin{array}{c}0.000 \\
(0.307)\end{array}$ & $\begin{array}{c}0.172 \\
(0.000)\end{array}$ & 0.011 \\
\hline
\end{tabular}

Notes: p-value between parentheses. The wavelet function used in all cases is a symmmlet, s8. 
Table 3 Spillovers after Controlling for Asymmetric GARCH effects and Serial Correlation (a) Spillovers from North America to Emerging Asia (EA)

\begin{tabular}{ccccc}
\hline \multicolumn{5}{c}{ Dependent variable: $\mathrm{R}_{\mathrm{t}}^{\mathrm{EA}}$} \\
Value & Std. error & $\mathrm{t}$-test & p-value \\
\hline Constant & $-5.574 \mathrm{e}-5$ & $1.432 \mathrm{e}-4$ & -0.389 & 0.349 \\
$\mathrm{R}_{\mathrm{t}-1} \mathrm{NA}$ & 0.334 & 0.021 & 15.658 & 0.000 \\
$\mathrm{R}_{\mathrm{t}-1}^{\mathrm{EA}}$ & 0.206 & 0.019 & 11.115 & 0.000 \\
\hline \multicolumn{5}{c}{ Variance equation } \\
Value & Std. error & t-test & p-value \\
\hline Constant & $1.459 \mathrm{e}-6$ & $6.028 \mathrm{e}-7$ & 2.420 & 0.008 \\
$\alpha$ & 0.101 & $2.368 \mathrm{e}-3$ & 4.256 & 0.000 \\
$\beta$ & 0.891 & $2.456 \mathrm{e}-3$ & 36.272 & 0.000 \\
$\gamma$ & -0.162 & 0.047 & -3.457 & 0.000 \\
\hline
\end{tabular}

No-residual ARCH effects test (12 lags $)=10.05$, $\mathrm{p}$-value $=0.612$

\begin{tabular}{ccccc}
\hline \multicolumn{5}{c}{ Dependent variable: $\mathrm{R}_{\mathrm{t}}^{\mathrm{EA}}$} \\
& Value & Std. error & $\mathrm{t}$-test & p-value \\
\hline Constant & $8.230 \mathrm{e}-5$ & $1.445 \mathrm{e}-4$ & 0.570 & 0.285 \\
$\mathrm{D} 1$ & 0.299 & 0.033 & 9.027 & 0.000 \\
$\mathrm{R}_{\mathrm{t}-1}$ EA & 0.246 & 0.018 & 13.272 & 0.000 \\
\hline \multicolumn{5}{c}{ Variance equation } \\
Constant & $1.437 \mathrm{e}-6$ & $5.535 \mathrm{e}-7$ & 2.597 & 0.005 \\
$\alpha$ & 0.099 & $2.184 \mathrm{e}-3$ & 4.557 & 0.000 \\
$\beta$ & 0.892 & 0.022 & 40.160 & 0.000 \\
$\gamma$ & -0.185 & $4.509 \mathrm{e}-3$ & -4.100 & 0.000 \\
\hline
\end{tabular}

No-residual ARCH effects test $(12$ lags $)=8.853$, $\mathrm{p}$-value $=0.716$

\begin{tabular}{ccccc}
\hline \multicolumn{5}{c}{ Dependent variable: $\mathrm{R}_{\mathrm{t}}^{\mathrm{EA}}$} \\
& Value & Std. error & t-test & $\mathrm{p}$-value \\
\hline Constant & $7.635 \mathrm{e}-5$ & $1.451 \mathrm{e}-4$ & 0.526 & 0.299 \\
D1+D2 $_{\text {EA }}$ & 0.295 & 0.025 & 11.700 & 0.000 \\
$\mathrm{R}_{\mathrm{t}-1}$ & 0.236 & 0.018 & 12.791 & 0.000 \\
\hline \multicolumn{5}{c}{ Variance equation } \\
\hline Constant & $1.423 \mathrm{e}-6$ & $5.349 \mathrm{e}-7$ & 2.661 & 0.004 \\
$\alpha$ & 0.101 & 0.021 & 4.729 & 0.000 \\
$\beta$ & 0.891 & 0.022 & 41.011 & 0.000 \\
$\gamma$ & -0.179 & 0.046 & -3.876 & 0.000 \\
\hline
\end{tabular}

No-residual ARCH effects test $(12$ lags $)=10.52$, $p$-value $=0.594$ 
(b) Spillovers from North America to Europe (EUR)

\begin{tabular}{ccccc}
\hline \multicolumn{5}{c}{ Dependent variable: $\mathrm{R}_{\mathrm{t}}^{\text {EUR }}$} \\
Value & Std. error & $\mathrm{t}$-test & $\mathrm{p}$-value \\
\hline Constant & $3.332 \mathrm{e}-5$ & $1.518 \mathrm{e}-4$ & 0.220 & 0.413 \\
$\mathrm{R}_{\mathrm{t}-1} \mathrm{NA}$ & 0.323 & 0.018 & 18.309 & 0.000 \\
$\mathrm{R}_{\mathrm{t}-1}$ EUR & -0.025 & 0.024 & -1.057 & 0.145 \\
\hline \multicolumn{5}{c}{ Variance equation } \\
\hline Vanstant & $2.771 \mathrm{e}-6$ & Std. error & $\mathrm{t}$-test & p-value \\
$\alpha$ & 0.101 & 0.055 & 1.133 & 0.129 \\
$\beta$ & 0.863 & 0.079 & 1.821 & 0.034 \\
$\gamma$ & -0.311 & 0.075 & -4.133 & 0.000 \\
\hline
\end{tabular}

No-residual ARCH effects test (12 lags $)=4.46$, p-value $=0.995$

\begin{tabular}{ccccc}
\hline \multicolumn{5}{c}{ Dependent variable: $\mathrm{R}_{\mathrm{t}}^{\text {EUR }}$} \\
Value & Std. error & $\mathrm{t}$-test & p-value \\
\hline Constant & $1.360 \mathrm{e}-4$ & 1.504 & 0.904 & 0.18 \\
$\mathrm{D} 1$ & 0.100 & 0.029 & 3.483 & 0.000 \\
$\mathrm{R}_{\mathrm{t}-1}$ EUR & 0.083 & 0.023 & 3.600 & 0.000 \\
\hline \multicolumn{5}{c}{ Variance equation } \\
\hline Constant & $2.164 \mathrm{e}-6$ & $1.123 \mathrm{e}-6$ & 1.927 & 0.027 \\
$\alpha$ & 0.076 & 0.023 & 3.423 & 0.000 \\
$\beta$ & 0.893 & 0.034 & 26.341 & 0.000 \\
$\gamma$ & -0.333 & 0.093 & -3.577 & 0.000 \\
\hline
\end{tabular}

No-residual ARCH effects test $(12$ lags $)=4.17$, p-value $=0.998$

\begin{tabular}{ccccc}
\hline \multicolumn{5}{c}{ Dependent variable: $\mathrm{R}_{\mathrm{t}}^{\text {EUR }}$} \\
Value & Std. error & $\mathrm{t}$-test & $\mathrm{p}$-value \\
\hline Constant & $1.636 \mathrm{e}-4$ & $1.482 \mathrm{e}-4$ & 1.104 & 0.135 \\
$\mathrm{D} 1+\mathrm{D} 2$ & 0.203 & 0.022 & 9.449 & 0.000 \\
$\mathrm{R}_{\mathrm{t}-1}$ EUR & 0.052 & 0.023 & 2.323 & 0.010 \\
\hline \multicolumn{5}{c}{ Variance equation } \\
\hline Constant & $1.963 \mathrm{e}-6$ & Std. error & $\mathrm{t}$-test & p-value \\
$\alpha$ & 0.076 & 0.026 & 1.756 & 0.040 \\
$\beta$ & 0.898 & 0.037 & 23.938 & 0.002 \\
$\gamma$ & -0.327 & 0.086 & -3.796 & 0.000 \\
\hline
\end{tabular}

No-residual ARCH effects test ( 12 lags $)=4.49$, p-value $=0.973$ 
(c) Spillovers from North America to Latin America (LA)

\begin{tabular}{ccccc}
\hline \multicolumn{5}{c}{ Dependent variable: $\mathrm{R}_{\mathrm{t}}^{\mathrm{LA}}$} \\
Value & Std. error & t-test & p-value \\
\hline Constant & $2.189 \mathrm{e}-4$ & $1.924 \mathrm{e}-4$ & 1.138 & 0.128 \\
$\mathrm{R}_{\mathrm{t}}^{\mathrm{NA}}$ & 0.606 & 0.025 & 24.695 & 0.000 \\
$\mathrm{R}_{\mathrm{t}-1}^{\mathrm{LA}}$ & 0.184 & 0.017 & 10.957 & 0.000 \\
\hline \multicolumn{5}{c}{ Variance equation } \\
\hline Constant & $9.497 \mathrm{e}-6$ & $2.793 \mathrm{e}-6$ & 3.400 & 0.000 \\
$\alpha$ & 0.117 & $2.146 \mathrm{e}-3$ & 5.461 & 0.000 \\
$\beta$ & 0.818 & 0.034 & 24.120 & 0.000 \\
$\gamma$ & -0.321 & 0.071 & -4.546 & 0.000 \\
\hline
\end{tabular}

No-residual ARCH effects test $(12$ lags $)=20.99$, p-value $=0.051$

\begin{tabular}{ccccc}
\hline \multicolumn{5}{c}{ Dependent variable: $\mathrm{R}_{\mathrm{t}}^{\mathrm{LA}}$} \\
Value & Std. error & t-test & p-value \\
\hline Constant & $4.008 \mathrm{e}-4$ & $2.052 \mathrm{e}-4$ & 1.953 & 0.025 \\
$\mathrm{D} 1$ & 0.576 & 0.041 & 14.221 & 0.000 \\
$\mathrm{R}_{\mathrm{t}-1}^{\text {LA }}$ & 0.246 & 0.019 & 13.132 & 0.000 \\
\hline \multicolumn{5}{c}{ Variance equation } \\
\hline Constant & $9.400 \mathrm{e}-6$ & $2.932 \mathrm{e}-6$ & 3.206 & 0.000 \\
$\alpha$ & 0.105 & 0.019 & 5.420 & 0.000 \\
$\beta$ & 0.836 & 0.031 & 27.011 & 0.000 \\
$\gamma$ & -0.367 & 0.082 & -4.500 & 0.000 \\
\hline
\end{tabular}

No-residual ARCH effects test $(12$ lags $)=12.73$, p-value $=0.389$

\begin{tabular}{ccccc}
\hline \multicolumn{5}{c}{ Dependent variable: $\mathrm{R}_{\mathrm{t}}^{\mathrm{LA}}$} \\
Value & Std. error & t-test & p-value \\
\hline Constant & $4.306 \mathrm{e}-4$ & $1.999 \mathrm{e}-4$ & 2.154 & 0.016 \\
D1+D2 $_{\text {LA }}$ & 0.590 & 0.028 & 20.723 & 0.000 \\
$\mathrm{R}_{\mathrm{t}-1}$ & 0.229 & 0.018 & 12.792 & 0.000 \\
\hline \multicolumn{5}{c}{ Variance equation } \\
\hline Constant & $9.251 \mathrm{e}-6$ & $2.942 \mathrm{e}-6$ & 3.144 & 0.000 \\
$\alpha$ & 0.109 & 0.021 & 5.322 & 0.000 \\
$\beta$ & 0.829 & 0.032 & 24.973 & 0.000 \\
$\gamma$ & -0.335 & 0.075 & -4.454 & 0.000 \\
\hline
\end{tabular}

No-residual ARCH effects test $(12$ lags $)=17.71, \mathrm{p}$-value $=0.185$ 
(d) Spillovers from Emerging Asia to North America

\begin{tabular}{ccccc}
\hline \multicolumn{5}{c}{ Dependent variable: $\mathrm{R}_{\mathrm{t}}^{\mathrm{NA}}$} \\
Value & Std. error & $\mathrm{t}$-test & p-value \\
\hline Constant & $2.166 \mathrm{e}-4$ & $1.326 \mathrm{e}-4$ & 1.634 & 0.051 \\
$\mathrm{R}_{\mathrm{t}}^{\mathrm{EA}}$ & 0.073 & 0.016 & 4.552 & 0.000 \\
$\mathrm{R}_{\mathrm{t}-1}{ }^{\mathrm{NA}}$ & 0.027 & 0.019 & 1.423 & 0.077 \\
\hline \multicolumn{5}{c}{ Variance equation } \\
Constant & $9.819 \mathrm{e}-7$ & $4.372 \mathrm{e}-7$ & 2.246 & 0.012 \\
$\alpha$ & 0.042 & 0.013 & 3.383 & 0.000 \\
$\beta$ & 0.932 & 0.018 & 52.238 & 0.000 \\
$\gamma$ & -0.600 & 0.167 & -3.598 & 0.000 \\
\hline
\end{tabular}

No-residual ARCH effects test $(12$ lags $)=3.807$, p-value $=0.999$

\begin{tabular}{ccccc}
\hline \multicolumn{5}{c}{ Dependent variable: $\mathrm{R}_{\mathrm{t}}^{\mathrm{NA}}$} \\
Value & Std. error & $\mathrm{t}$-test & $\mathrm{p}$-value \\
\hline Constant & $2.374 \mathrm{e}-4$ & $1.312 \mathrm{e}-4$ & 1.810 & 0.035 \\
$\mathrm{D} 1$ & -0.114 & 0.036 & -3.130 & 0.000 \\
$\mathrm{R}_{\mathrm{t}-1}{ }^{\mathrm{N}}$ & 0.073 & 0.018 & 3.943 & 0.000 \\
\hline \multicolumn{5}{c}{ Variance equation } \\
Constant & $1.031 \mathrm{e}-6$ & Std. error & $\mathrm{t}$-test & $\mathrm{p}$-value \\
$\alpha$ & 0.046 & $0.016 \mathrm{e}-7$ & 2.567 & 0.000 \\
$\beta$ & 0.928 & 0.017 & 3.806 & 0.000 \\
$\gamma$ & -0.564 & 0.149 & -3.756 & 0.000 \\
\hline
\end{tabular}

No-residual ARCH effects test $(12$ lags $)=5.701$, $\mathrm{p}$-value $=0.930$

\begin{tabular}{ccccc}
\hline \multicolumn{5}{c}{ Dependent variable: $\mathrm{R}_{\mathrm{t}}^{\mathrm{NA}}$} \\
Value & Std. error & $\mathrm{t}$-test & $\mathrm{p}$-value \\
\hline Constant & $2.665 \mathrm{e}-4$ & $1.312 \mathrm{e}-4$ & 2.019 & 0.022 \\
$\mathrm{D} 1+\mathrm{D} 2$ & 0.005 & 0.027 & 0.228 & 0.410 \\
$\mathrm{R}_{\mathrm{t}-1}{ }^{\mathrm{TA}}$ & 0.057 & 0.018 & 3.095 & 0.002 \\
\hline \multicolumn{5}{c}{ Variance equation } \\
\hline Constant & $9.438 \mathrm{e}-7$ & $4.000 \mathrm{e}-7$ & 2.358 & 0.009 \\
$\alpha$ & 0.042 & 0.012 & 3.602 & 0.000 \\
$\beta$ & 0.934 & 0.017 & 55.880 & 0.000 \\
$\gamma$ & -0.589 & 0.152 & -3.887 & 0.000 \\
\hline
\end{tabular}

No-residual ARCH effects test $(12$ lags $)=4.22$, $\mathrm{p}$-value $=0.979$ 
(e) Spillovers from Europe to North America

\begin{tabular}{ccccc}
\hline \multicolumn{5}{c}{ Dependent variable: $\mathrm{R}_{\mathrm{t}}^{\mathrm{NA}}$} \\
Value & Std. error & $\mathrm{t}$-test & $\mathrm{p}$-value \\
\hline Constant & $1.411 \mathrm{e}-4$ & $1.275 \mathrm{e}-4$ & 1.107 & 0.134 \\
$\mathrm{R}_{\mathrm{t}}^{\mathrm{EUR}}$ & 0.317 & 0.020 & 15.465 & 0.000 \\
$\mathrm{R}_{\mathrm{t}-1}^{\mathrm{NA}}$ & -0.052 & 0.018 & -2.906 & 0.002 \\
\hline \multicolumn{5}{c}{ Variance equation } \\
\hline Constant & $1.164 \mathrm{e}-6$ & Std. error & $\mathrm{t}$-test & p-value \\
$\alpha$ & $0.04114 \mathrm{e}-7$ & 2.829 & 0.002 \\
$\beta$ & 0.925 & 0.011 & 3.734 & 0.000 \\
$\gamma$ & -0.712 & 0.015 & 62.721 & 0.000 \\
\hline
\end{tabular}

No-residual ARCH effects test $(12$ lags $)=4.503$, p-value $=0.995$

\begin{tabular}{ccccc}
\hline \multicolumn{5}{c}{ Dependent variable: $\mathrm{R}_{\mathrm{t}}^{\mathrm{NA}}$} \\
& Value & Std. error & $\mathrm{t}$-test & $\mathrm{p}$-value \\
\hline Constant & $2.172 \mathrm{e}-4$ & $1.328 \mathrm{e}-4$ & 1.635 & 0.051 \\
$\mathrm{D} 1$ & 0.092 & 0.031 & 3.011 & 0.001 \\
$\mathrm{R}_{\mathrm{t}-\mathrm{NA}}$ & 0.052 & 0.017 & 2.936 & 0.002 \\
\hline \multicolumn{5}{c}{ Variance equation } \\
Constant & Value & Std. error & $\mathrm{t}$-test & p-value \\
$\alpha$ & $1.110 \mathrm{e}-6$ & $4.630 \mathrm{e}-7$ & 2.398 & 0.008 \\
$\beta$ & 0.045 & 0.011 & 4.005 & 0.000 \\
$\gamma$ & 0.929 & 0.017 & 53.366 & 0.000 \\
\hline
\end{tabular}

No-residual ARCH effects test $(12$ lags $)=4.019, p$-value $=0.998$

\begin{tabular}{ccccc}
\hline \multicolumn{5}{c}{ Dependent variable: $\mathrm{R}_{\mathrm{t}}^{\mathrm{NA}}$} \\
& Value & Std. error & $\mathrm{t}$-test & p-value \\
\hline Constant & $2.470 \mathrm{e}-4$ & $1.315 \mathrm{e}-4$ & 1.879 & 0.030 \\
$\mathrm{D} 1+\mathrm{D} 2$ & 0.221 & 0.023 & 9.438 & 0.000 \\
$\mathrm{R}_{\mathrm{t}-\mathrm{NA}}$ & 0.019 & 0.018 & 1.061 & 0.144 \\
\hline \multicolumn{5}{c}{ Variance equation } \\
\hline Constant & Value & Std. error & $\mathrm{t}$-test & p-value \\
$\alpha$ & $1.176 \mathrm{e}-7$ & $4.275 \mathrm{e}-7$ & 2.751 & 0.003 \\
$\beta$ & 0.047 & 0.010 & 4.500 & 0.000 \\
$\gamma$ & 0.924 & 0.016 & 58.362 & 0.000 \\
\hline
\end{tabular}

No-residual ARCH effects test $(12$ lags $)=5.296$, p-value $=0.947$ 
(f) Spillovers from Latin America to North America

\begin{tabular}{ccccc}
\hline \multicolumn{5}{c}{ Dependent variable: $\mathrm{R}_{\mathrm{t}}^{\mathrm{NA}}$} \\
Value & Std. error & t-test & p-value \\
\hline Constant & $1.572 \mathrm{e}-4$ & $1.300 \mathrm{e}-4$ & 1.209 & 0.113 \\
$\mathrm{R}_{\mathrm{t}}^{\mathrm{LA}}$ & 0.210 & 0.018 & 11.128 & 0.000 \\
$\mathrm{R}_{\mathrm{t}-1}{ }^{\mathrm{NA}}$ & -0.287 & 0.017 & -0.170 & 0.433 \\
\hline \multicolumn{5}{c}{ Variance equation } \\
Constant & $8.395 \mathrm{e}-7$ & $3.340 \mathrm{e}-7$ & 2.514 & 0.006 \\
$\alpha$ & 0.046 & $9.571 \mathrm{e}-3$ & 4.778 & 0.000 \\
$\beta$ & 0.938 & 0.013 & 72.392 & 0.000 \\
$\gamma$ & -0.379 & 0.097 & -3.912 & 0.000 \\
\hline
\end{tabular}

No-residual ARCH effects test $(12$ lags $)=4.696$, p-value $=0.993$

\begin{tabular}{ccccc}
\hline \multicolumn{5}{c}{ Dependent variable: $\mathrm{R}_{\mathrm{t}}^{\mathrm{NA}}$} \\
Value & Std. error & t-test & p-value \\
\hline Constant & $2.164 \mathrm{e}-4$ & $1.316 \mathrm{e}-4$ & 1.645 & 0.050 \\
$\mathrm{D} 1$ & 0.186 & 0.023 & 8.094 & 0.000 \\
$\mathrm{R}_{\mathrm{t}-1}^{\mathrm{NA}}$ & 0.079 & 0.018 & 4.473 & 0.002 \\
\hline \multicolumn{5}{c}{ Variance equation } \\
Constant & $1.078 \mathrm{e}-6$ & $3.789 \mathrm{e}-7$ & 2.845 & 0.002 \\
$\alpha$ & 0.045 & $8.730 \mathrm{e}-3$ & 5.266 & 0.000 \\
$\beta$ & 0.928 & 0.014 & 68.721 & 0.000 \\
$\gamma$ & -0.552 & 0.137 & -4.043 & 0.000 \\
\hline
\end{tabular}

No-residual ARCH effects test $(12$ lags $)=4.255$, p-value $=0.978$

\begin{tabular}{ccccc}
\hline \multicolumn{5}{c}{ Dependent variable: $\mathrm{R}_{\mathrm{t}}^{\mathrm{NA}}$} \\
Value & Std. error & t-test & p-value \\
\hline Constant & $2.415 \mathrm{e}-4$ & $1.313 \mathrm{e}-4$ & 1.840 & 0.033 \\
$\mathrm{D} 1+\mathrm{D} 2^{\mathrm{NA}}$ & 0.203 & 0.019 & 11.174 & 0.000 \\
$\mathrm{R}_{\mathrm{t}-1}$ & 0.055 & 0.017 & 3.328 & 0.001 \\
\hline \multicolumn{5}{c}{ Variance equation } \\
Constant & $9.709 \mathrm{e}-7$ & $3.422 \mathrm{e}-7$ & 2.837 & 0.002 \\
$\alpha$ & 0.044 & $9.908 \mathrm{e}-3$ & 4.452 & 0.000 \\
$\beta$ & 0.934 & 0.013 & 71.716 & 0.000 \\
$\gamma$ & -0.492 & 0.127 & -3.868 & 0.000 \\
\hline
\end{tabular}

No-residual ARCH effects test $(12$ lags $)=5.296$, p-value $=0.947$ 
Table 4 Linear Regressions for Conditional Volatility of North America Returns

(a) Latin America model

\begin{tabular}{lcccc}
\hline & Coefficient & Std. error & t-statistic & $\mathrm{p}$-value \\
\hline Intercept & -0.003 & $4 . \mathrm{e}-4$ & -7.773 & 0.000 \\
A-PARCH volatility & 1.522 & 0.045 & 34.017 & 0.000 \\
\hline $\mathrm{R}^{2}=0.256$ & & & \\
\hline
\end{tabular}

(b) Europe model

\begin{tabular}{lcccc}
\hline & Coefficient & Std. error & t-statistic & p-value \\
\hline Intercept & -0.002 & $4 . e-4$ & -6.230 & 0.000 \\
A-PARCH volatility & 1.380 & 0.040 & 34.739 & 0.000 \\
\hline $\mathrm{R}^{2}=0.264$ & & & \\
\hline
\end{tabular}

Note: The dependent variable is the absolute value of the daily return on the North America index (naive estimate). The Latin American model corresponds with a regression on the contemporaneous return on the North America index on its first lag and the (D1+D2) crystal of the return on the Latin America Index, after controlling for asymmetric GARCH effects. The A-PARCH volatility is the in-sample conditional volatility yielded by this model. In turn, the Europe model corresponds with a regression on the contemporaneous return on the North America index on its first lag and the (D1+D2) crystal of the return on the Europe Index, after controlling for asymmetric GARCH effects. The A-PARCH volatility is the in-sample conditional volatility yielded by this model. 


\section{FIGURES}

Figure 1 Different Orthogonal Wavelets

(a) Mother Wavelets
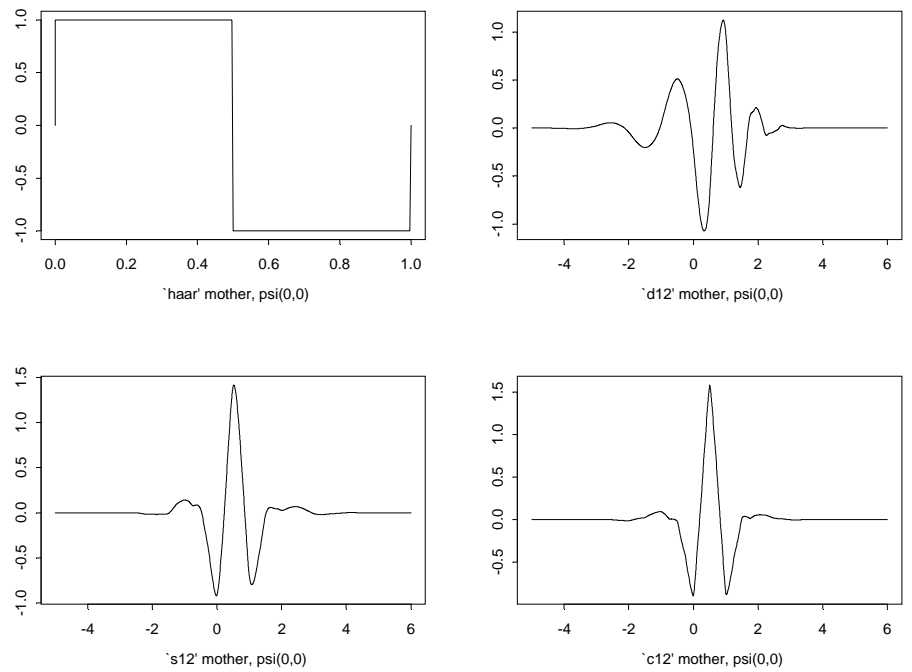

(b) Father Wavelets
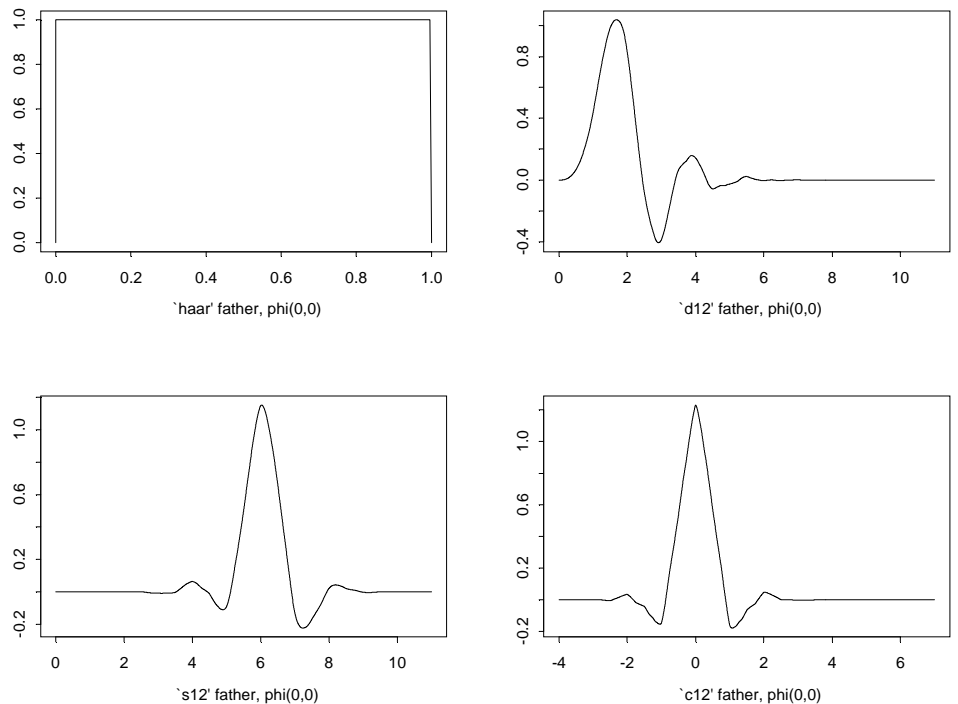

Note: $\mathrm{d} 12$ is a daublet, s12 is a symmlet, and $\mathrm{c} 12$ is a coiflet. The number is related to the width and smoothness of the wavelet function. For instance, the c24 wavelet is wider and smoother than the 12 wavelet. (See Bruce and Gao, 1996). 
Figure 2 Multiresolution Decomposition of Returns

Latin America

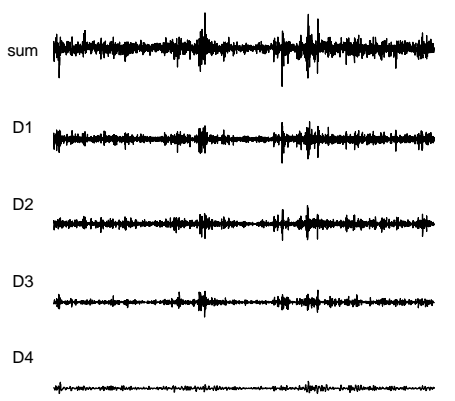

D5

S6

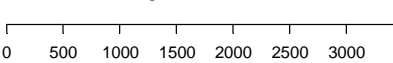

Emerging Asia

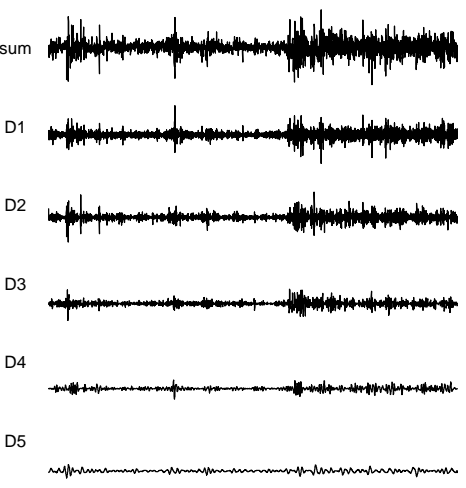

D6

S6

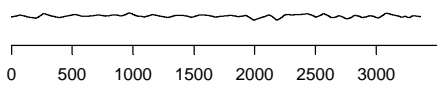

North America

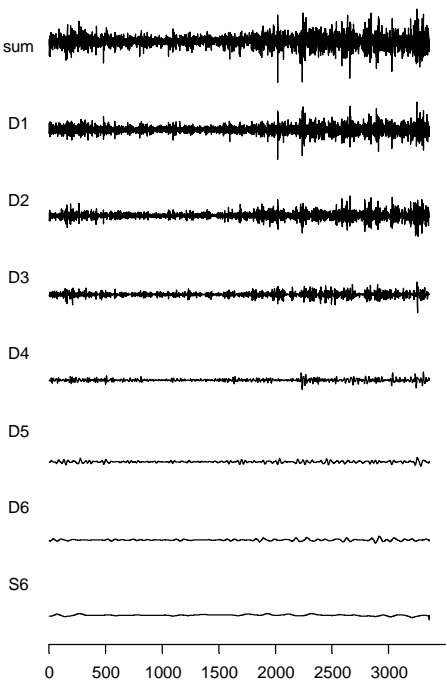

Europe

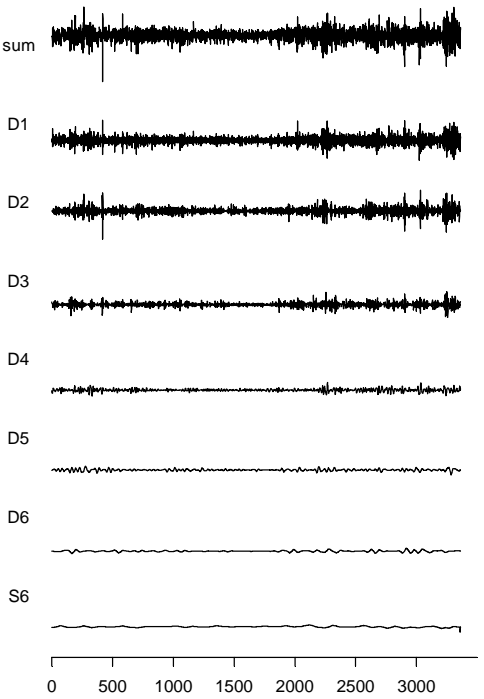


Europe and Middle East

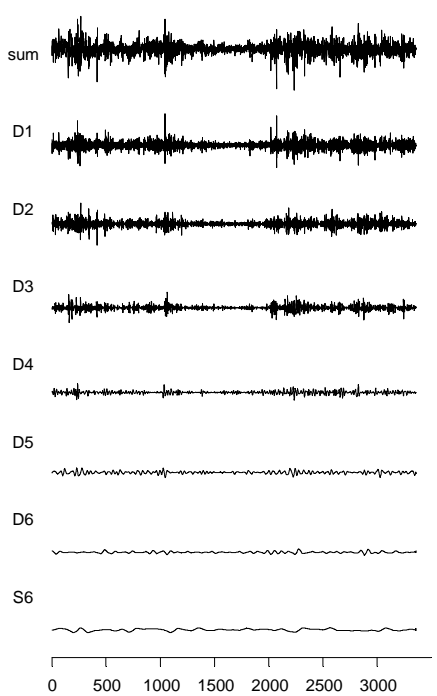

Far East
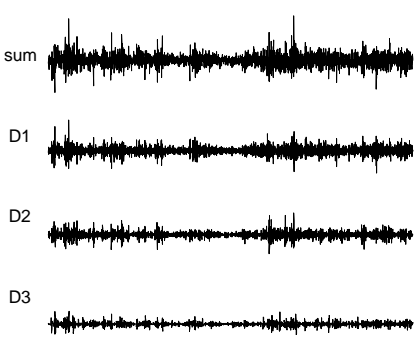

D4

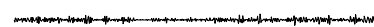

D
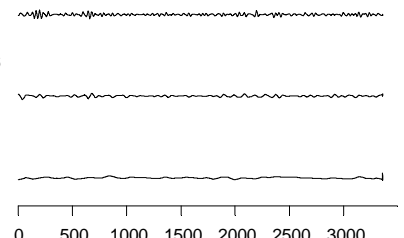

Pacific

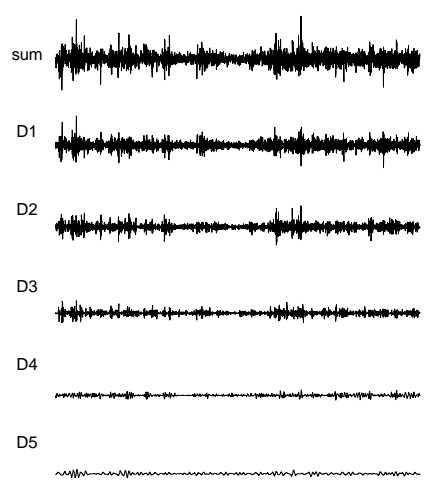

D6

$\begin{array}{llllll}500 & 1000 & 1500 & 2000 & 2500 & 3000\end{array}$

G7

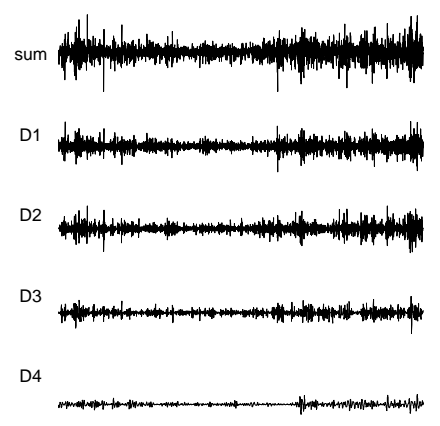

D5

D6

S6

$\begin{array}{llllll}500 \quad 1000 & 1500 \quad 2000 \quad 2500 & 3000\end{array}$

Note: The wavelet function used in all cases is a symmmlet, $\mathrm{s} 8$. 
Figure 3 Latin America on the G7 using crystals D1 and D5
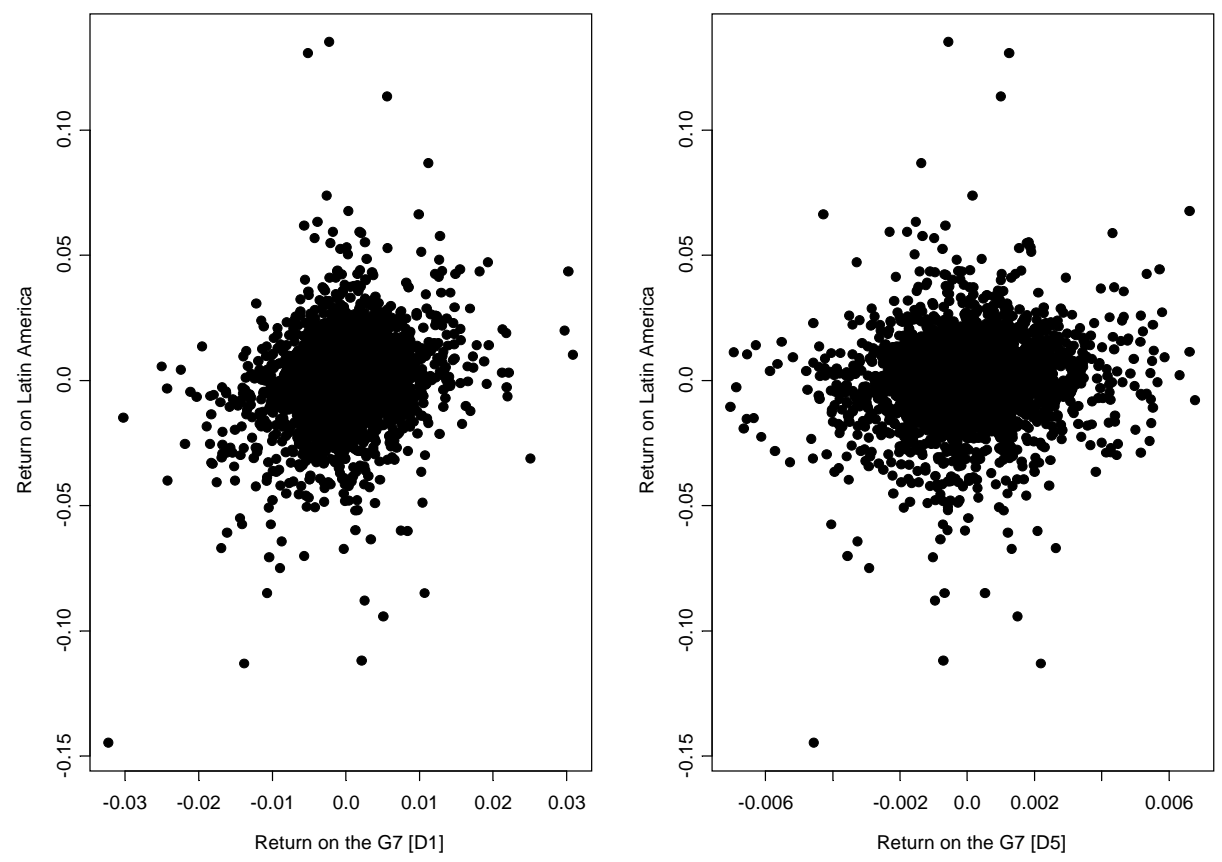

Note: The left-hand side plot shows the Latin America daily return on the first crystal (D1) of the G7 daily return, while the right-hand side plot shows the Latin America daily return on the fifth crystal (D5) of the G7 daily return. The wavelet function used is a symmmlet, s8.

Figure 4 Models for Predicting North America Returns

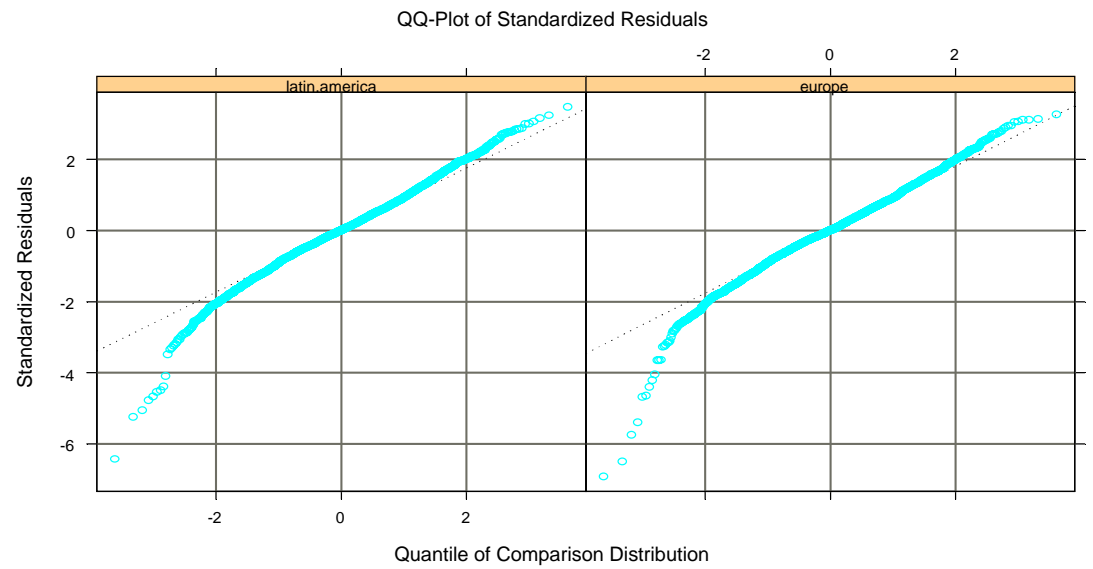

Note: The Latin American model on the left-hand side corresponds with a regression on the contemporaneous return on the North America index on its first lag and the (D1+D2) crystal of the return on the Latin America Index, after controlling for asymmetric GARCH effects. In turn, the Europe model on the right-hand side corresponds with a regression on the contemporaneous return on the North America index on its first lag and the (D1+D2) crystal of the return on the Europe Index, after controlling for asymmetric GARCH effects. 
Figure 5 Value at risk in and out of Sample for North America

(a) 1-day horizon

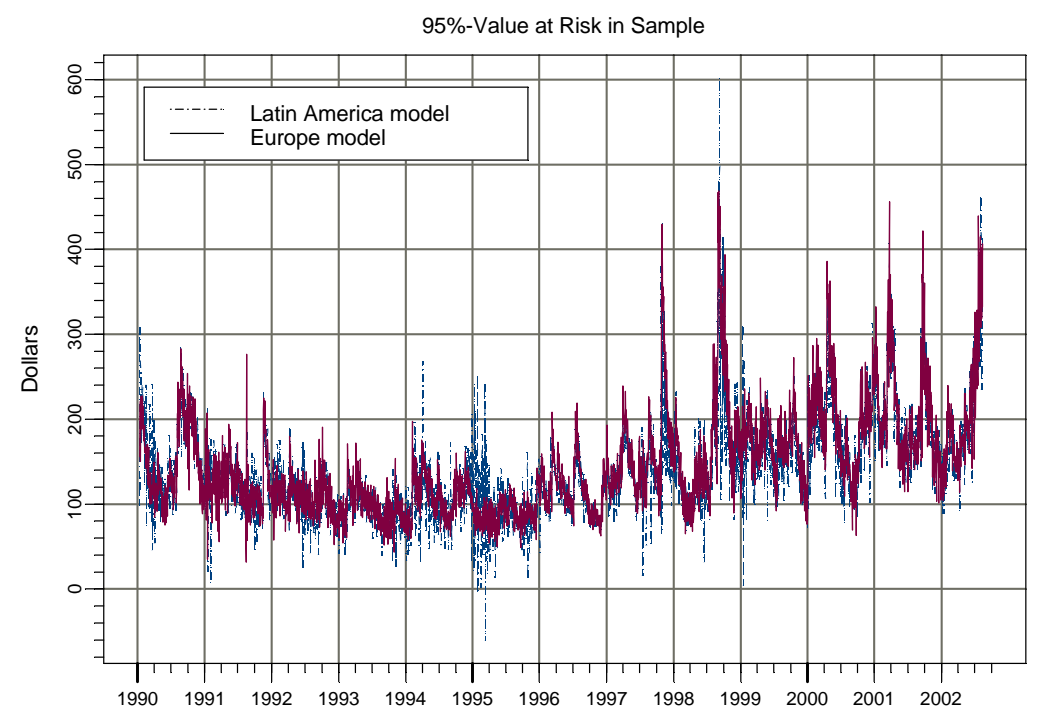

(b) k-day horizon

$95 \%$-Value at Risk Out of Sample

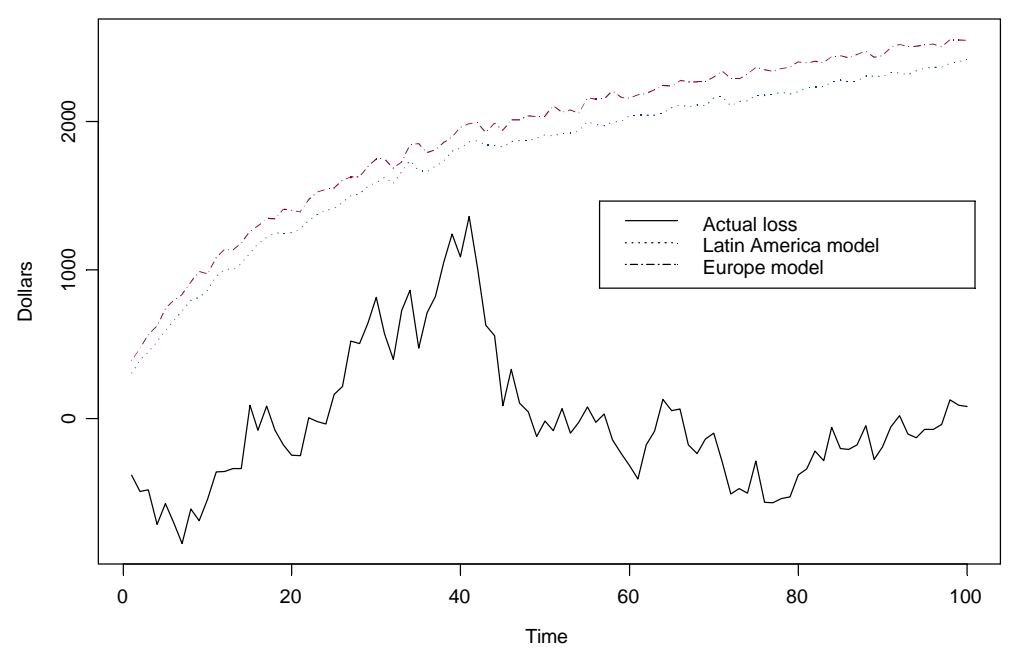

Note: The amount invested is $\$ 10,000$. 